\title{
Major and Trace Element Geochemistry of Pyrite and Pyrrhotite from Stratiform and Lamellar Orebodies: Implications for the Ore Genesis of the Dongguashan Copper (Gold) Deposit, Eastern China
}

\author{
Zhongfa Liu ${ }^{1}$, Yongjun Shao ${ }^{1}$, Haodi Zhou ${ }^{2}$, Nan Liu ${ }^{3}$, Kuanxin Huang ${ }^{1}$, Qingquan Liu $1,4, *$ (1), \\ Jiandong Zhang ${ }^{1}$ and Cheng Wang ${ }^{1}$ \\ 1 Key Laboratory of Metallogenic Prediction of Nonferrous Metals and Geological Environment \\ Monitoring (Central South University), Ministry of Education, Changsha 410083, China; \\ liuzf61521@csu.edu.cn (Z.L.); shaoyongjun@csu.edu.cn (Y.S.); hkx_1986@126.com (K.H.); \\ csuzjd@sina.com (J.Z.); csuwangcheng@csu.edu.cn (C.W.) \\ 2 Hunan Key Laboratory of Land and Resources Evaluation and Utilization, Changsha 410007, China; \\ haodi.zhou@csu.edu.cn \\ 3 Hunan Institute of Geological Survey, Changsha 410116, China; liujiweiliang302@163.com \\ 4 School of Resources and safety engineering, Central South University, Changsha 410083, China \\ * Correspondence: liuqingquan@csu.edu.cn; Tel.: +86-731-888-30616
}

Received: 28 May 2018; Accepted: 24 August 2018; Published: 1 September 2018

\begin{abstract}
The Dongguashan copper (gold) deposit in Anhui Province is one of the largest copper (gold) deposits in the Tongling ore district, which is the most important region in the Middle-Lower Yangtze River Metallogenic Belt, Eastern China. Stratiform and lamellar orebodies are the major deposit types. Pyrite and pyrrhotite from the stratiform deposit type (Py I, Po I) and lamellar deposit type (Py II, Po II) are investigated using Electron-probe Microanalyses (EPMA) and Laser Ablation Inductively Coupled Plasma Mass Spectrometry (LA-ICP-MS). Py I, Py II, Po I and Po II have high contents of $\mathrm{Cu}, \mathrm{Co}, \mathrm{Au}$ and $\mathrm{Se}$, low contents of $\mathrm{As}, \mathrm{Pb}$ and $\mathrm{Zn}$, with $\mathrm{Co} / \mathrm{Ni}$ ratios of $0.50-48.00$, $4.00-45.00,1.55-14.45$ and 1.02-1.36, respectively, most of which are greater than 1 and vary widely; these characteristics are consistent with those of pyrite with a magmatic-hydrothermal origin. The higher $\mathrm{Au} / \mathrm{Ag}$ and $\mathrm{Fe} /(\mathrm{S}+\mathrm{As})$ ratios of pyrite and crystallization temperatures $\left(286-387^{\circ} \mathrm{C}\right)$ of hexagonal pyrrhotite indicate that the mineralization occurrs in environments with medium- to high-temperatures, high sulfur fugacity and medium-shallow depths. Therefore, we suggest that the Dongguashan copper (gold) deposit is a stratabound skarn-type ore deposit associated with magma intrusion activity during the Yanshanian Period.
\end{abstract}

Keywords: EPMA and LA-ICP-MS; major and trace elements; pyrite and pyrrhotite; Dongguashan copper (gold) deposit; Tongling ore district

\section{Introduction}

As minerals represent the most basic units of rocks and/or ore, their chemical composition and type are of great significance when discussing the origins of rocks and/or ore, as well as the ore genesis and the ore-forming environment $[1,2]$. Due to the influence of factors, such as the purity of single minerals and the interference associated with solid solutions, the data obtained using traditional chemical analyses for single phases have large errors. The rapid development of Electron-Probe Microanalyses (EPMA) and Laser Ablation Inductively Coupled Plasma Mass Spectrometry (LA-ICP-MS) has realized in situ analysis of single minerals at the nanoscale, which has 
solved the problem of the large errors in traditional analytical methods. So far, these in situ analytical methods have been widely applied to study on the ore-forming environments, ore-forming material source, ore-forming processes, and ore genesis [1,3-10].

The Tongling ore district in Anhui Province, which is enriched in $\mathrm{Cu}, \mathrm{Fe}$, and $\mathrm{Au}$, is one of the most important regions in the Middle-Lower Yangtze River Metallogenic Belt, Eastern China (Figure 1). Five major deposits have been discovered in this ore district, including the Dongguashan $\mathrm{Cu}-\mathrm{Au}$, Shizishan $\mathrm{Cu}-\mathrm{Au}$, Tongguanshan $\mathrm{Cu}-\mathrm{Fe}$, Fenghuangshan $\mathrm{Cu}-\mathrm{Fe}$ and Xinqiao Cu-S-Fe deposits. In the last few years, researchers have carried out many in-depth studies of these deposits in the Tongling ore district. Different ore genetic models have been established, which mainly include the stratabound-skarn model [11], the "multi-story building"-type model [12,13], the generalized skarn-porphyry-type hydrothermal model [14] and the porphyry-skarn-manto-type model [15].

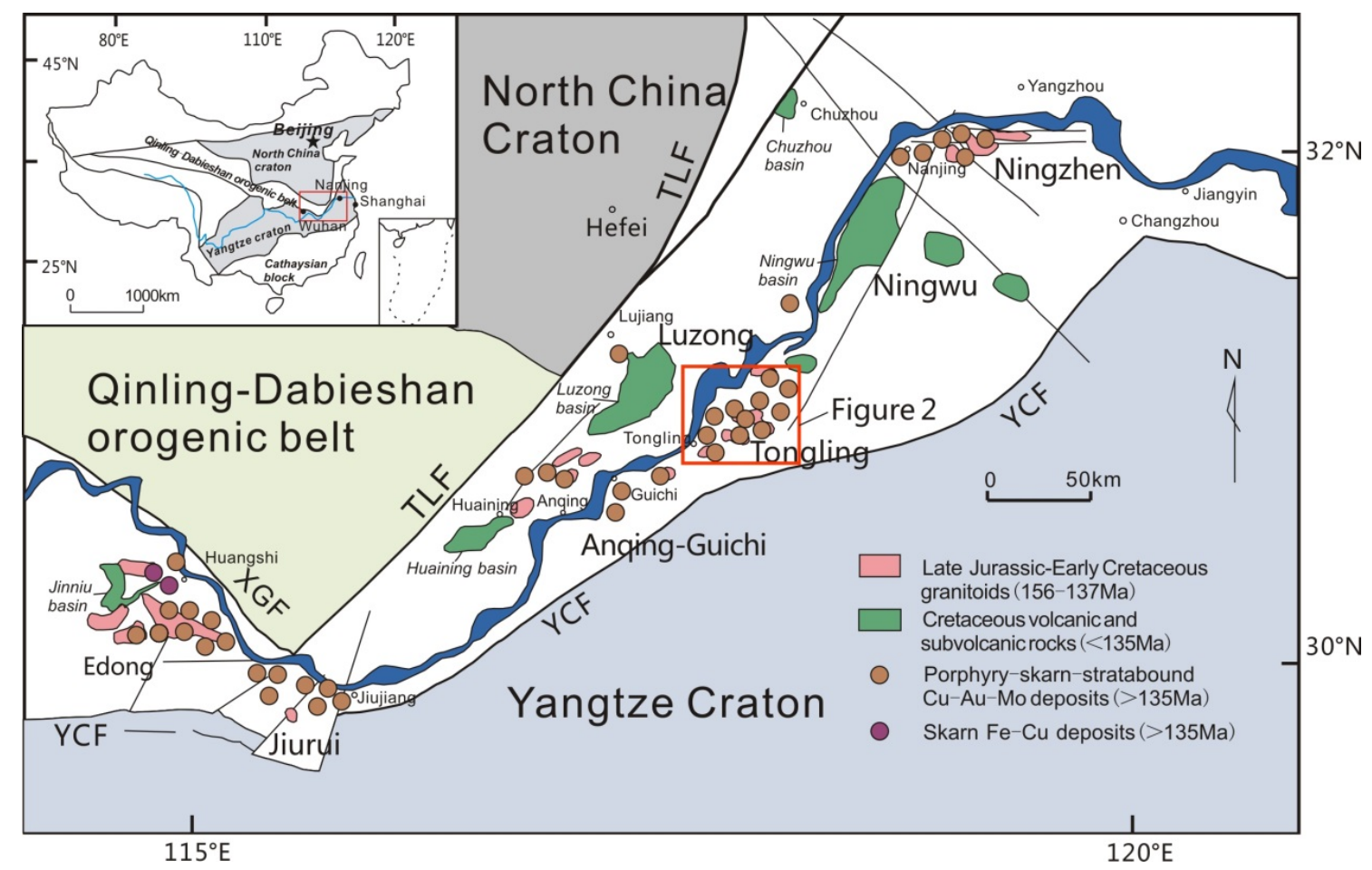

Figure 1. Geological map showing the location of the Tongling ore district, and related porphyry-skarn-stratabound $\mathrm{Cu}-\mathrm{Au}-\mathrm{Mo}$ (>135 Ma) deposits along the Middle-Lower Yangtze River Valley Metallogenic Belt [16]. Faults: TLF-Tancheng-Lujiang fault, XGF-Xiangfan-Guangji fault, YCF-Yangxing-Changzhou fault.

The Dongguashan copper (gold) ore deposit is one of the largest copper (gold) deposits in the Tongling ore district, and it is located approximately $7 \mathrm{~km}$ to the east of Tongling city (Figure 2), Anhui Province, Eastern China. It is controlled by stratigraphic horizons, anticlines, and interlayered structures. The major stratiform and lamellar orebodies in the Dongguashan deposit are distributed along the northern core and limbs of the Qingshan anticline, and they are hosted in the limestones of the Middle and Upper Carboniferous Huanglong and Chuanshan formations. The Dongguashan copper (gold) deposit, with its unique geological characteristics, has attracted a lot of attention to geologists for a long time. A great deal of scientific progress has been made in identifying the source of ore-forming materials and fluids, rock- and ore-forming ages, and ore genesis [17-26]. However, as far as the ore genesis of the Dongguashan copper (gold) deposit is concerned, questions remain, as this deposit has been proposed to be a stratabound skarn-type [15,23,25,27-29], exhalative sedimentary and hydrothermal superimposition-type [21,22,30-36], and exhalative sedimentary-type deposit [19,37-39]. 


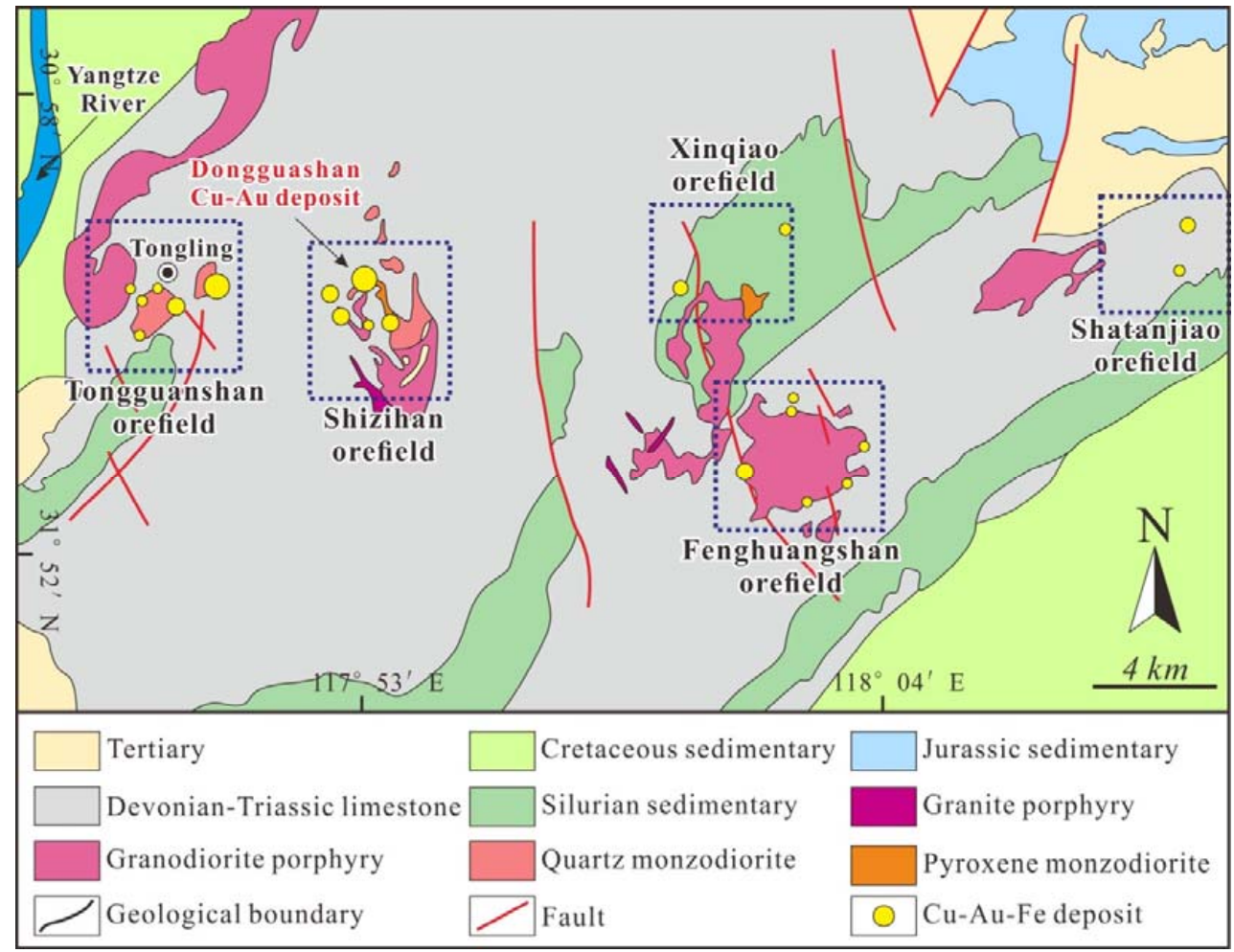

Figure 2. Geological map of the Tongling ore district [27,40].

Questions regarding deposit genesis is mainly focused on stratiform and lamellar orebodies. It will be helpful for us to understand the ore genesis by determining their geneses. In this paper, we are going to study the major and trace element compositions of pyrite and pyrrhotite in stratiform and lamellar orebodies by using EPMA and LA-ICP-MS and to constrain the ore genesis.

\section{Geological Setting}

The Tongling ore district is located in the northeastern section of the Lower Yangtze area, in the junction between North China and the Yangtze Block. This ore district is bounded by the Xiangfan-Guangji fault to the north, the Tanlu fault to the northeast, and the Yangxing-Changzhou fault to the south (Figure 1). A three-stage tectonic evolution of the Lower Yangtze area has been proposed, i.e., the formation of Pre-Sinian (Late Neoproterozoic) basement, the development of Sinian to Early Triassic sedimentary cover, and intraplate deformation from the Middle Triassic to the Cenozoic [41-43]. The EW-trending basement faults, NE- and NNE-trending folds and associated interformational fracture zones are the major structures. The outcropping strata mainly consist of Silurian to Triassic neritic- and littoral-facies sedimentary carbonate rocks [44]. Yanshanian intermediate-acid intrusive rocks are widely distributed in this area [45], and their rock-forming ages dated from $135 \mathrm{Ma}$ to $147 \mathrm{Ma}$ [46]. The mineralization is dominated by copper, iron, gold, lead and zinc, showing an east-west trending zonation ranging from lead to zinc rich in the north and south and from copper to gold rich in the middle.

The Dongguashan copper (gold) ore deposit is situated at the intersection of the EW-trending Tongling-Shatanjiao tectonic-magmatic belt and the Qingshan anticline of the NE-trending Shun'an synclinorium [23,47] (Figures 2 and 3). The mineralization is mainly related to the siliceous and argillaceous hornfels of the Upper Devonian Wutong Formation, impure carbonate of the Middle to Upper Carboniferous Chuanshan and Huanglong formations, and bioclastic limestone and skarn of the Lower Permian Qixia Formation. There are NE-trending folds and SN-, EW- and NNE-trending faults in the Dongguashan deposit. The NE-trending Qingshan anticline and the associated interformational 
fracture zones between the Carboniferous and Devonian strata are the most important ore-controlling structures in this area. The complex structure network in this area provides channels for the ascent and emplacement of magma during the Yanshanian period. The Qingshanjiao quartz monzodiorite is closely related to the mineralization in the Dongguashan deposit [29].

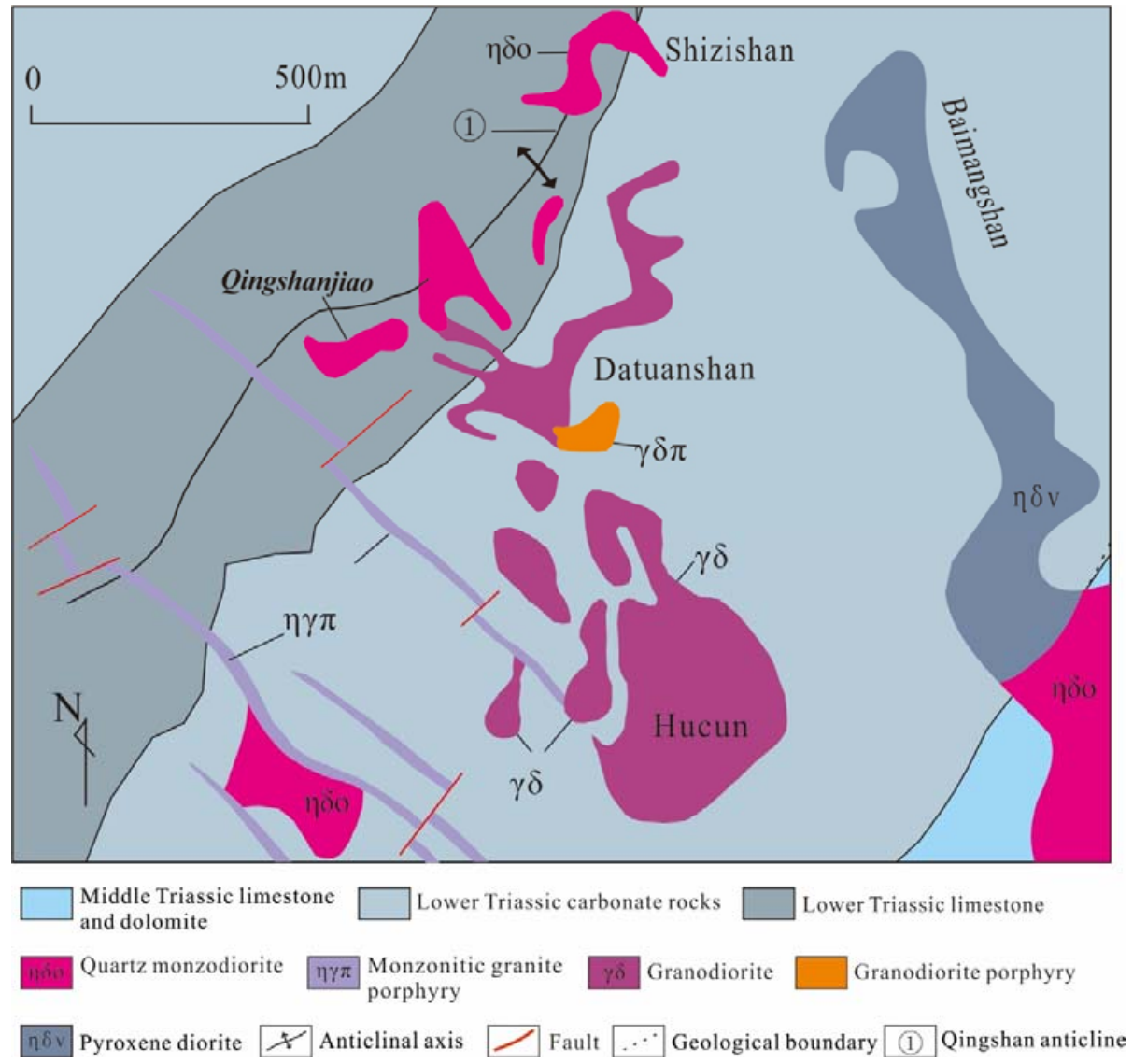

Figure 3. Geological map of the Shizishan ore field [30].

The types of orebodies in the Dongguashan deposit include stratiform, lamellar, porphyry and vein-like orebodies. The stratiform orebody is the major orebody, which is distributed along the northern core and limbs of the Qingshan anticline and hosted in the limestones of the Middle and Upper Carboniferous Huanglong and Chuanshan formations. It is NE-striking and generally tends to plunge to the northeast, and it is in concordance with the occurrence of the surrounding rocks. The major stratiform orebody is controlled by the strata, interlayered structures, and contact zones between the Qingshanjiao pluton and its wall rocks. The metal minerals in the major orebody are mainly magnetite, pyrrhotite, pyrite and chalcopyrite, with minor bornite, chalcocite, sphalerite, tetrahedrite, molybdenite, galena, and native gold. The gangue minerals include quartz, calcite, garnet, diopside, and epidote, with minor actinolite, tremolite and anhydrite. A thin lamellar orebody is developed at the bottom of the stratiform orebody, which consists of serpentine, tremolite, talc, pyrite, pyrrhotite and chalcopyrite. The vein-like or veinlet-disseminated orebodies are mainly distributed in the upper part of the Qingshanjiao pluton and close to its wall rocks. The porphyry-type orebody is mainly developed inside the Qingshanjiao pluton and contains chalcopyrite, pyrite, potash feldspar, plagioclase and quartz. Based on their ore fabric characteristics and spatial output locations, the ore types can be classified as massive, vein-like, lamellar, and disseminated ores. The ores have massive, lamellar, vein-like and disseminated structures and granular, metasomatic and exsolution textures (Figure 4). The wall rock alteration of the Dongguashan copper (gold) deposit is well developed, as is evident 
by the presence of altered minerals, including garnet, diopside, forsterite, quartz, K-feldspar, sericite, serpentine, calcite, hornfels and chlorite, with minor anhydrite and talc. The enrichment of metal minerals is closely related to the skarnization, silicification and retrograde alteration of early skarn.

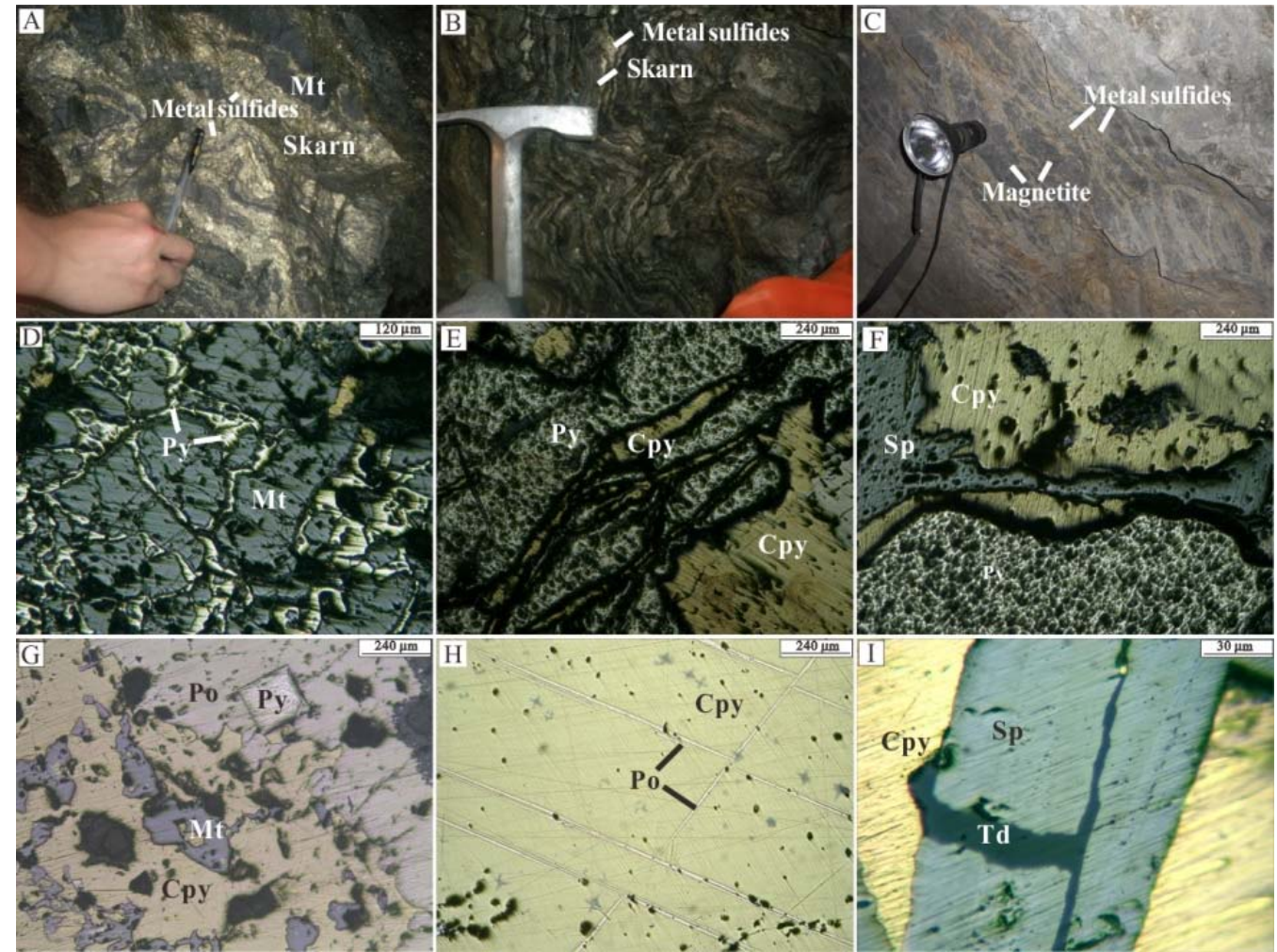

Figure 4. Typical ore structure and texture of the Dongguashan deposit. (A,B) Magnesian skarn and metal sulfides present as laminated structure. (C) Magnetite intruded by ore sulfide veins. (D) Magnetite intruded by pyrite (reflected light). (E) Vein-like chalcopyrite penetrating pyrite (reflected light). (F) Vein-like sphalerite penetrating chalcopyrite (reflected light). (G) Pyrrhotite contains pyrite (reflected light). (H) Chalcopyrite and pyrrhotite with exsolution texture (reflected light). (I) Tetrahedrite fills the fissure in sphalerite. Abbreviations: Py-Pyrite, Mt-Magnetite, Ccp-Chalcopyrite, Po-Pyrrhotite, Sp-Sphalerite, Td-Tetrahedrite, Bn-Bornite.

Based on field investigations and microscopic observations of mineralogy and mineral associations, the mineralization can be divided into three skarn development stages: the skarn stage, retrograde-altered stage and quartz-carbonate stage. The skarn stage is composed of garnet, diopside and humite. The retrograde-altered stage, which is the main mineralization stage, predominantly contains chalcopyrite, pyrite, magnetite, pyrrhotite, sphalerite, chalcocite, serpentine, epidote, quartz and talc. The quartz-carbonate stage is mainly characterized by the veil-like output of late quartz and calcite, accompanied by a small amount of metal sulfides.

\section{Sampling and Analytical Methods}

\subsection{Electron-Probe Microanalyses}

The pyrite (Py I) samples used for EPMA were collected from the massive ores of the stratiform orebody (sample DGS1-9, 3-4, 3-5 and 3-6), and the pyrite (Py II) samples were collected from the lamellar ores of the lamellar orebody (DGS1-7, 4-17, 5-16, 7 and 19-1). Samples DGS1-7, 1-9, 7, and 19-1 were collected from exploration line 59 of the 850-m underground mining level, and samples DGS3-4, 3-5, 3-6, 4-17 and 5-16 were collected from line 66 of the 850-m underground 
mining level. The pyrrhotite (Po I) samples used for EPMA were collected from the massive ores (samples DGS3-5, 5-9 and 17), and the pyrrhotite (Po II) samples were collected from the lamellar ores (DGS3-14 and 3-16). Sample DGS17 was collected from exploration line 59 of the 850-m underground mining level; samples DGS3 -5, 3-14, 5-9 and 3-16 were collected from line 66 of the 850-m underground mining level; and sample DGS4-17 was collected from line 46 of the 730-m underground mining level. EPMA with backscattered electron image observations and X-ray elemental mapping were conducted using a Shimadzu EPMA-1720H electron microprobe (Japan) at the Key Laboratory of Metallogenic Prediction of Nonferrous Metals and Geological Environment Monitoring (Central South University), Ministry of Education, China. The operating conditions of the electron microprobe included an accelerating voltage of $15 \mathrm{kV}$, a beam current of $60 \mathrm{nA}$, and an electron beam diameter of $1 \mu \mathrm{m}$. The analytical procedure was detailed in [48]. All data were corrected using a standard ZAF routine. The minimum detection limits of the elements are $\leq 0.01 \mathrm{wt} . \%$.

\subsection{Laser Ablation Inductively Coupled Plasma Mass Spectrometry Trace Element Analysis}

This analysis was completed at Akita University in Japan. The microelement analysis instrument was an Agilent 7500i quadrupole ICP-MS mass spectrometer, employing a New Wave Research 5906 system. The laser beam frequency was $6 \mathrm{~Hz}$, the energy was $850 \mathrm{MJ}$, and the analysis point size was $45 \mu \mathrm{m}$. At each analysis point, the data collection included $30 \mathrm{~s}$ of gas background value measurement, $30 \mathrm{~s}$ of a mass spectrometry standard sample ablation, and $30 \mathrm{~s}$ of sample ablation. The minimum detection limits of the elements were $\leq 0.01 \mathrm{ppm}$.

\section{Results}

\subsection{Analysis Results of Electron Probe Microanalysis}

\subsubsection{Pyrite}

The results of the EPMA analyses of pyrite from the massive (Py I) and lamellar ores (Py II) are listed in Appendix A.

The S and Fe contents of Py I range from 51.27 to 54.78 wt.\% and from 45.56 to 48.03 wt.\%, with average values of $53.07 \mathrm{wt} . \%$ and $47.02 \mathrm{wt.} \%$, respectively (Appendix A). The contents of Co and $\mathrm{Ni}$ range from 0.01 to $0.96 \mathrm{wt} . \%$ and from 0.01 to $0.06 \mathrm{wt} . \%$, with average values of $0.21 \mathrm{wt} . \%$ and $0.02 \mathrm{wt} . \%$, respectively. The contents of As, Au and Ag are 0.01-0.82 wt. \%, 0.02-0.22 wt.\% and $0.02-0.29 \mathrm{wt} . \%$, with corresponding average values of $0.19 \mathrm{wt} . \%, 0.09 \mathrm{wt} . \%$ and $0.05 \mathrm{wt} . \%$, respectively. The ratios of $\mathrm{S} / \mathrm{Fe}, \mathrm{Co} / \mathrm{Ni}, \mathrm{Au} / \mathrm{Ag}$ and $\mathrm{Fe} /(\mathrm{S}+\mathrm{As})$ are 1.87-2.05, 0.50-48.00, 0.13-8.94 and 0.84-0.89, with corresponding average values of $1.97,42.80,2.74$ and 0.89 , respectively (Appendix A).

The S and Fe contents of Py II range from 50.52 to $54.04 \mathrm{wt.} \%$ and from 46.56 to $48.04 \mathrm{wt} . \%$, with average values of $52.99 \mathrm{wt} . \%$ and $47.31 \mathrm{wt} . \%$, respectively (Appendix A). The contents of Co and $\mathrm{Ni}$ range from 0.02 to $0.45 \mathrm{wt} . \%$ and from 0.01 to $0.03 \mathrm{wt} . \%$, with average values of $0.16 \mathrm{wt} . \%$ and $0.01 \mathrm{wt} . \%$, respectively. The contents of As, Au and Ag are 0.02-0.61 wt. \%, 0.03-0.20 wt.\% and $0.01-0.09 \mathrm{wt} . \%$, with corresponding average values of $0.26 \mathrm{wt} . \%, 0.09 \mathrm{wt} . \%$ and $0.03 \mathrm{wt} . \%$, respectively. The ratios of $\mathrm{S} / \mathrm{Fe}, \mathrm{Co} / \mathrm{Ni}, \mathrm{Au} / \mathrm{Ag}$ and $\mathrm{Fe} /(\mathrm{S}+\mathrm{As})$ are 1.85-2.00, 4.00-45.00, 1.32-33.00 and 0.87-0.94, with corresponding average values of $1.95,19.64,10.21$ and 0.89 , respectively (Appendix A).

\subsubsection{Pyrrhotite}

The results of the EPMA analyses of pyrrhotite from the massive (Po I) and lamellar ores (Po II) are listed in Appendix B.

The S and Fe contents of Po I range from 38.38 to 39.96 wt.\% and from 59.82 to $62.00 \mathrm{wt} . \%$, with average values of $38.85 \mathrm{wt} . \%$ and $60.71 \mathrm{wt} . \%$, respectively (Appendix B, Figure $5 \mathrm{a}$ ). The contents of As, Au and Ag are 0.01-0.10 wt.\%, 0.03-0.17 wt.\% and 0.01-0.04 wt.\%, with corresponding average values of $0.05 \mathrm{wt} . \%, 0.08 \mathrm{wt} . \%$ and $0.02 \mathrm{wt} . \%$, respectively. The Fe atomic percent (at.\%) values range 
from 46.98 to $48.35 \%$, with an average value of $47.28 \%$. The Au/Ag ratios range from 1.94 to 4.18 , with an average value of 3.06 (Appendix B).
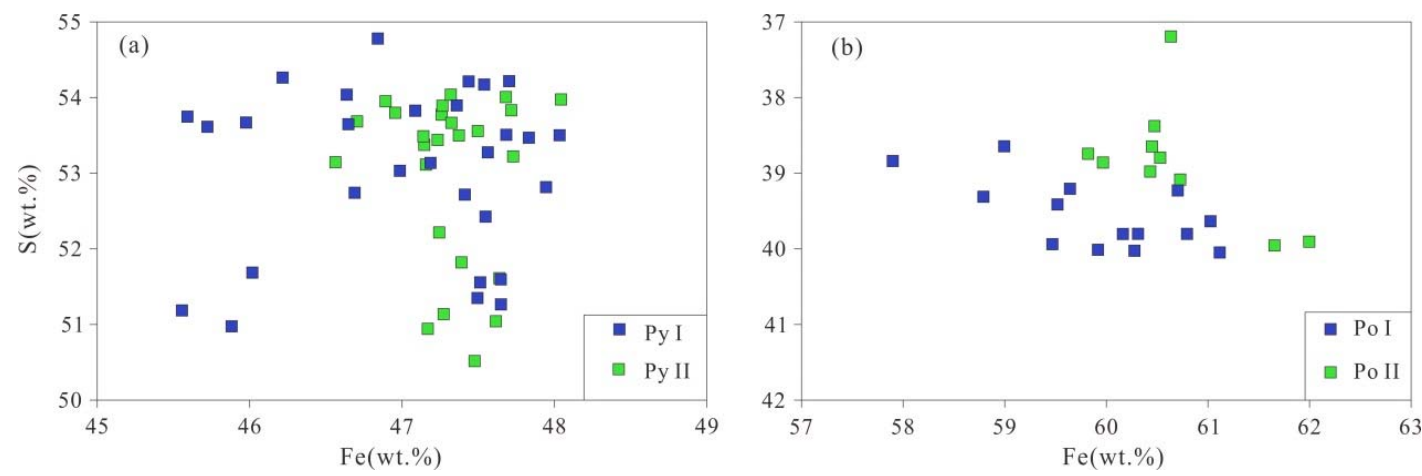

Figure 5. Fe vs. S diagrams for pyrite (a) and pyrrhotite (b) from massive and lamellar ores of the Dongguashan copper (gold) deposit.

The S and Fe contents of Po II range from 38.64 to 40.05 wt.\% and from 58.79 to $61.12 \mathrm{wt} . \%$, with average values of $39.55 \mathrm{wt} . \%$ and $59.90 \mathrm{wt} . \%$, respectively (Appendix B, Figure $5 \mathrm{~b}$ ). The contents of As, Au and Ag are 0.06-0.16 wt.\%, 0.02-0.12 wt.\% and 0.02-0.04 wt.\%, with corresponding average values of $0.09 \mathrm{wt} . \%, 0.06 \mathrm{wt} . \%$ and $0.027 \mathrm{wt} . \%$, respectively. The Fe atomic percent (at.\%) values range from 46.09 to $47.05 \%$, with an average value of $46.52 \%$. The $\mathrm{Au} / \mathrm{Ag}$ ratios range from 1.25 to 4.87 , with an average value of 3.06 (Appendix B).

\subsection{Analysis Results of Laser Ablation Inductively Coupled Plasma Mass Spectrometry}

\subsubsection{Pyrite}

Py I and Py II have only minor geochemical differences. Py I records wide ranges of $\mathrm{Cu}$ (0.04-461.81 ppm, average: 79.65 ppm), Mn (0.46-12.48 ppm, average: 2.46 ppm), Zn (1.04-15.83 ppm, average: $7.42 \mathrm{ppm}$ ) and Se (3.49-75.77 ppm, average: $41.80 \mathrm{ppm})$, and narrow ranges of Sn (0.14-0.54 ppm), Te (2.16-4.51 ppm) and $\mathrm{Hg}(0.14-1.29 \mathrm{ppm})$. Py II records wider ranges of $\mathrm{Cu}$ (1.02-1311.82 ppm, average: $191.86 \mathrm{ppm}$ ) and Mn (0.04-129.07 ppm, average: $21.57 \mathrm{ppm}$ ) (Appendix C, Figure 6). The Py II samples from lamellar ores have higher $\mathrm{Cu}$ and $\mathrm{Mn}$ contents compared to the Py I samples from massive ores.
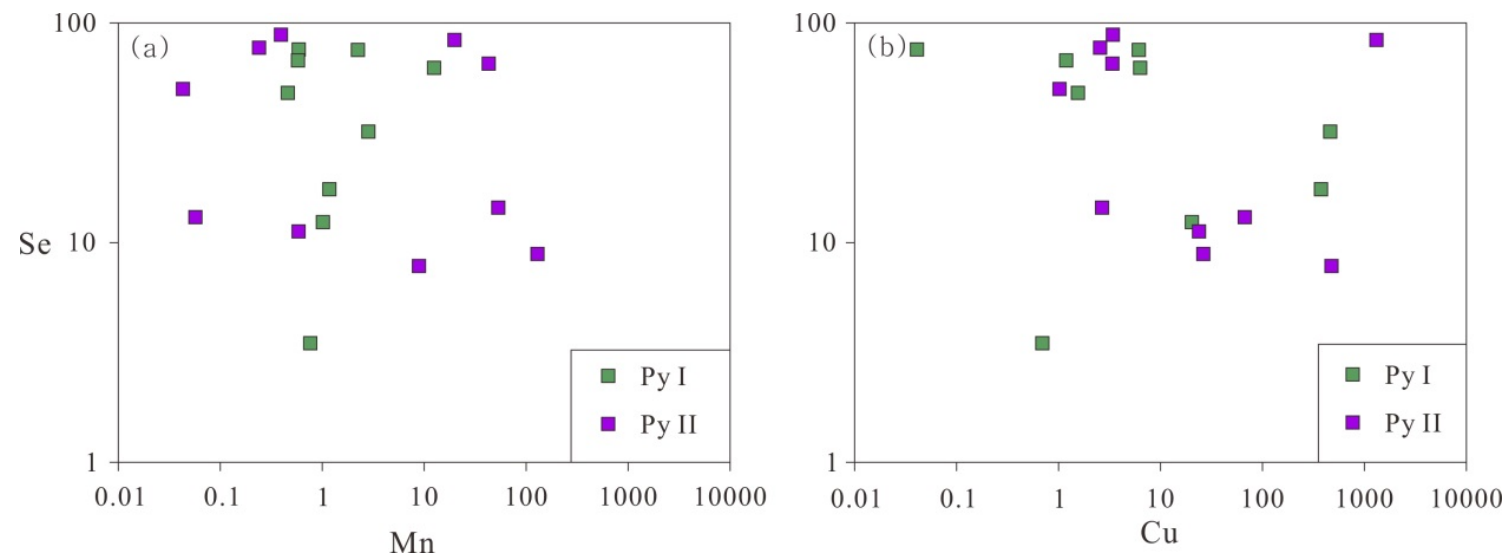

Figure 6. Mn vs. Se diagram (a) and Cu vs. Se diagram (b) for pyrite from massive and lamellar ores of the Dongguashan copper (gold) deposit. 


\subsubsection{Pyrrhotite}

The Co and Ni contents of Po I range from 0.20 to $32.81 \mathrm{ppm}$ and from 0.13 to $20.84 \mathrm{ppm}$, with average values of $10.70 \mathrm{ppm}$ and $5.06 \mathrm{ppm}$, respectively (Appendix D). The Co and Ni contents of Po II range from 1.23 to $1.93 \mathrm{ppm}$ and from 1.21 to $1.42 \mathrm{ppm}$, with average values of $1.58 \mathrm{ppm}$ and $1.32 \mathrm{ppm}$, respectively. Compared to Po II, the Po I samples have higher Co, Ni and Se contents (Appendix D). The Co/Ni ratios of Po I and Po II are 1.55-14.45 and 1.02-1.36, with corresponding average values of 4.22 and 1.19, respectively. The Po I samples from the massive ore has higher $\mathrm{Cu}$ contents compared to the Po II samples from the lamellar ore.

\section{Discussion}

\subsection{Implications for Ore-Forming Environment}

The Fe atomic percent values of hexagonal pyrrhotite and monoclinic pyrrhotite are $47.0-47.8$ at. $\%$ and $46.5-47.0$ at.\%, respectively [49]. These data indicate that the pyrrhotite in the Dongguashan deposit mainly contains hexagonal and monoclinic pyrrhotite. The Fe atomic percent and content of pyrrhotite reach up to 48.35 at.\% and $60.64 \mathrm{wt} . \%$ in the sample DGS 5-9 (collected in the stratiform orebody), respectively, which is similar to the composition of pyrrhotite in the corresponding mantle inclusion [50]. Using the $T-x(\mathrm{Fe})$ imitative straight-line equation of $\mathrm{y}=-201.22 x+9854.32$ ( $\mathrm{y}$ is the temperature, $x$ is the Fe atomic percent [51]), the crystallization temperatures of monoclinic pyrrhotite were calculated. The results show that the crystallization temperatures of monoclinic pyrrhotite range from 286 to $387^{\circ} \mathrm{C}$, with an average value of $353^{\circ} \mathrm{C}$, indicating that different pyrrhotites formed in a medium- to high-temperature environment. In general, the Co contents of high-temperature pyrite, medium-temperature pyrite and low-temperature pyrite are $>1000 \mathrm{ppm}, 100-1000 \mathrm{ppm}$ and $<100 \mathrm{ppm}$, respectively [52]. The larger value of the $\mathrm{Co} / \mathrm{Ni}$ implies the higher temperature of pyrite formation [53]. The Co contents of Py I and Py II are 0.009-0.96 wt.\% (90-9600 ppm) and 0.02-0.45 wt.\% (200-4500 ppm), with corresponding average values of $0.21 \mathrm{wt} . \%(2100 \mathrm{ppm})$ and $0.16 \mathrm{wt} . \%$ (1600 ppm), respectively (Appendix A). This supports the conclusions that Py I and Py II were formed in mediumand high-temperature environments. Arsenic can replace $S$ isomorphically in pyrite, and As tends to be enriched in low-temperature systems [2]. Most of the As contents of Py I and Py II are below the detection limit, indicating that the ore-forming system is a high-temperature system. Moreover, Py I and Py II have high Au/Ag ratios (most >1, Figure 7a, Appendix A), which are different from those of sedimentary/diagenetic pyrite [6,54], reflecting that the Dongguashan copper (gold) deposit has a medium- to high-temperature hydrothermal genesis [55]. Py I and Py II are depleted in $\mathrm{Ni}, \mathrm{As}, \mathrm{Pb}$, $\mathrm{Te}$ and $\mathrm{Sb}$, which are different from those of synsedimentary pyrite [56], according to the geochemical characteristics of the high temperature hydrothermal pyrite [2]. The higher contents of $\mathrm{Mn}, \mathrm{Cu}$, Se and Zn show some similarity with the skarn deposit [57].

As mentioned above, different pyrites and pyrrhotites are formed in medium- to high-temperature environments, which is supported by the temperature measurement results of fluid inclusions in the same mineralization stage (retrograde-altered stage) (fluid inclusion temperature: $220-450{ }^{\circ} \mathrm{C}$, average: $\left.325.6{ }^{\circ} \mathrm{C}[24]\right)$.

The $\mathrm{Fe} /(\mathrm{S}+\mathrm{As})$ ratio values of pyrite exhibit good correlation with their formation depth; the ratios of deep formation environments, medium-depth environments and shallow environments are $0.846,0.863$ and 0.926 , respectively [56]. The Fe/(S + As) ratio values of Py I and Py II in the Dongguashan copper (gold) deposit range from 0.84 to 0.93 and from 0.87 to 0.94 , with corresponding average values of 0.89 and 0.89 , respectively (Appendix A). These data show that the formation environment of pyrite and pyrrhotite is an epithermal environment.

The presence of abundant pyrite indicates that there is sufficient sulfur. Pyrrhotite is mainly monoclinic pyrrhotite, with a small amount of hexagonal pyrrhotite, which indicates that it experienced a rapid cooling process and higher sulfur fugacity [58]. As mentioned above, the Dongguashan deposit formed in a medium-high temperature, high sulfur fugacity and epithermal environment. 


\subsection{Source of Ore-Forming Materials}

The source of ore-forming materials of the Dongguashan copper (gold) deposit has not yet been well constrained. Based on the $\mathrm{S}$ and $\mathrm{Pb}$ isotope analyses, $\mathrm{Xu}[23,59]$ proposed that the ore-forming materials mainly originate from magma. Xu [18] considered that the underlying Paleozoic strata are an important metallogenic metal source area. Hou [35] and Cao [26] suggested that the ore-forming materials are derived from both sedimentary strata and magma. Lu [60] considered that the ore-forming materials are derived from a Hercynian submarine exhalative event. However, Liu [25] suggested that in the Qingshanjiao pluton, Py I and Py II have similar S and Pb isotopic compositions, and thus that Yanshanian magmatic activity plays a key role in copper (gold) mineralization. The in situ trace element analyses of single pyrite and pyrrhotite grains more effectively constrain the source of the ore-forming materials. Most pyrite crystals show low Bi contents ( $<1$ ppm, Appendix C, Figure $7 b$ ). High Zn, Cd and Bi contents in pyrite probably indicate a sedimentary source [61]. In Figure 7b, most of Bi contents are less than 1 ppm, suggesting that there is no sediment influence for pyrite. Magmatic volatiles possibly cause the high Bi contents ( $>1 \mathrm{ppm})$ of very few points [61]. Therefore, the source of ore-forming materials of the Dongguashan copper (gold) deposit is not a sedimentary source.
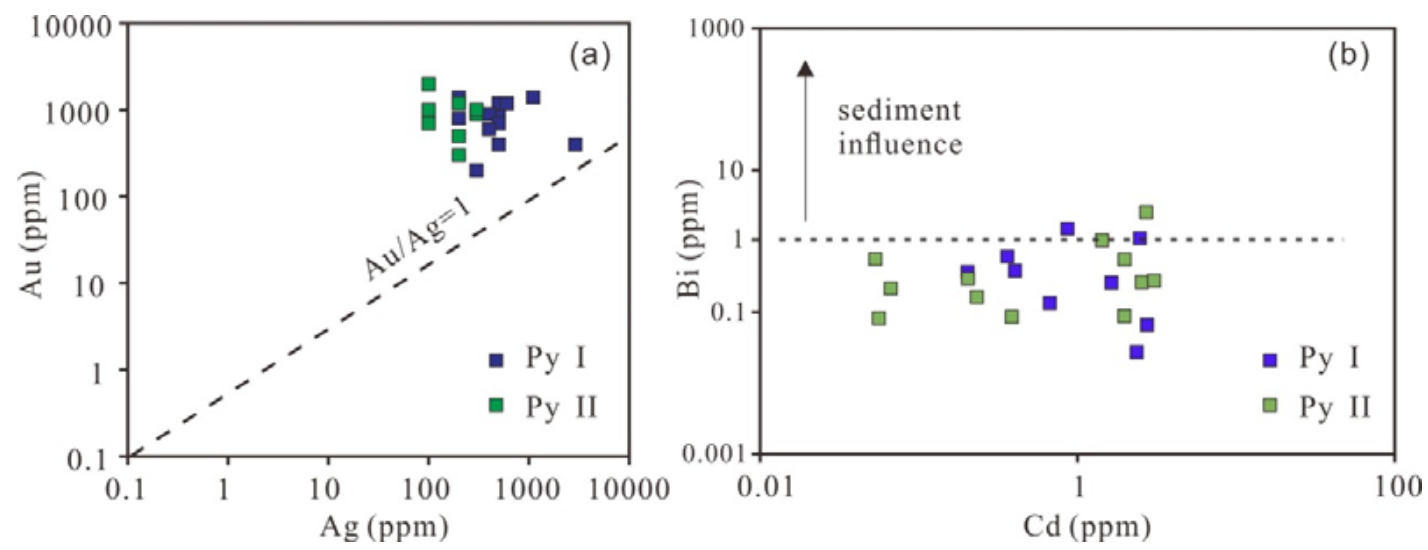

Figure 7. The $\mathrm{Au}$ and $\mathrm{Ag}$ contents and $\mathrm{Au} / \mathrm{Ag}$ ratios in pyrite (a) and Cd vs. Bi diagram for Pyrite from massive and lamellar ores of the Dongguashan copper (gold) deposit (b) (Reference [61]).

The high Au contents in pyrite and pyrrhotite suggest that Au may originate from magma [62,63]. The Cu contents of Py I, Py II, Po I and Po II are 0.04-461.81 ppm, 1.02-1311.82 ppm, 6.3-15,806.7 ppm and 29.0-3576.9 ppm, with corresponding average values of 79.65 ppm, $191.86 \mathrm{ppm}, 3961.38 \mathrm{ppm}$ and 1802.97 ppm, respectively (Appendixs C and D), which are far higher than that obtained by Vinogradov (47 ppm, Vinogradov [64]). In addition, Py I, Py II, Po I and Po II have high Au and low Pb and $\mathrm{Zn}$ contents (Appendixs C and D), which supports the inference that the ore-forming materials may have been mainly derived from magma that contains abundant $\mathrm{Cu}$ and $\mathrm{Au}$. This is consistent with the lack of galena and sphalerite in this area. As mentioned above, the source of ore-forming metals may have been sourced from mantle-derived magma.

\subsection{Implications for Ore Genesis}

In general, hydrothermal pyrite is depleted in sulfur, and sedimentary pyrite is rich in sulfur or close to its theoretical value [65]. The S/Fe atomic ratio values of Py I and Py II in the Dongguashan deposit are 1.87-2.05 and 1.85-2.00, with corresponding average values of 1.97 and 1.95 (Appendix A), respectively, thus showing sulfur-deficient characteristics [66-68]. This observation suggests that both Py I and Py II are hydrothermal-origin pyrite. The Co and Ni contents in pyrite and pyrrhotite can reflect the origin of pyrite, as well as its ore genesis and geological setting [69-71]. The Co/Ni ratios of sedimentary pyrite and magmatic-hydrothermal pyrite have values of $\mathrm{Co} / \mathrm{Ni}<1$ and $\mathrm{Co} / \mathrm{Ni}>1$, 
respectively $[1,65,69,72]$. The Co/Ni ratios of Py I, Py II, Po I and Po II are 0.50-48.00, 4.00-45.00, 1.55-14.45 and 1.02-1.36, respectively (Appendix A). The As/ Au ratios of Py I and Py II are 0.13-20.50 and $0.20-20.33$, respectively. The Sb/ Au ratios of Py I and Py II are 0.07-6.14 and 0.08-0.67, respectively (Appendix A). As/ $\mathrm{Au}$ and $\mathrm{Sb} / \mathrm{Au}$ ratios are less than those of sedimentary pyrite (As/ $\mathrm{Au}>200$, $\mathrm{Sb} / \mathrm{Au}>100,[54,73])$. Most of the $\mathrm{Co} / \mathrm{Ni}$ ratios are greater than 1 and vary widely, which are consistent with the characteristics of pyrite with a magmatic-hydrothermal origin [74].

The Se contents of Py I and Py II in the Dongguashan deposit are 3.49-75.77 ppm and $7.83-87.40 \mathrm{ppm}$, with corresponding average values of $41.80 \mathrm{ppm}$ and $34.56 \mathrm{ppm}$, respectively. These are greater than that of sedimentary pyrite $(0.5-2 \mathrm{ppm})$, but they are similar to the Se contents (>20 ppm) of magmatic-hydrothermal-origin pyrite (Appendix C) [65]. Thus, it can be seen that Py I and Py II are magmatic-hydrothermal origins in this area. Large [6] studied the contents of trace elements in pyrites of different origins and used the changes in their $\mathrm{Ni}-\mathrm{Au}$ contents to discriminate between pyrites formed by diagenesis and/or hydrothermal processes. In the Ni vs. Au discrimination diagram (Figure 8a), the samples of Py I and Py II fall within the field of hydrothermal pyrite. In the $\mathrm{Zn}$ vs. Pb discrimination diagram (Figure 8 b), the samples of Py I and Py II fall within and near the field of hydrothermal pyrite. In the Co vs. Ni discrimination diagram (Figure 9), the samples of Py I and Py II mainly fall within the field of magmatic, and hydrothermal pyrite partially fall within the field of sedimentary pyrite, which may be related to the mixing of crustal materials. The samples of Po I and Po II fall near the deposit related to magmatic-hydrothermal solutions. Overall, the elemental contents indicate that Py I, Py II, Po I and Po II are magmatic-hydrothermal genesis.
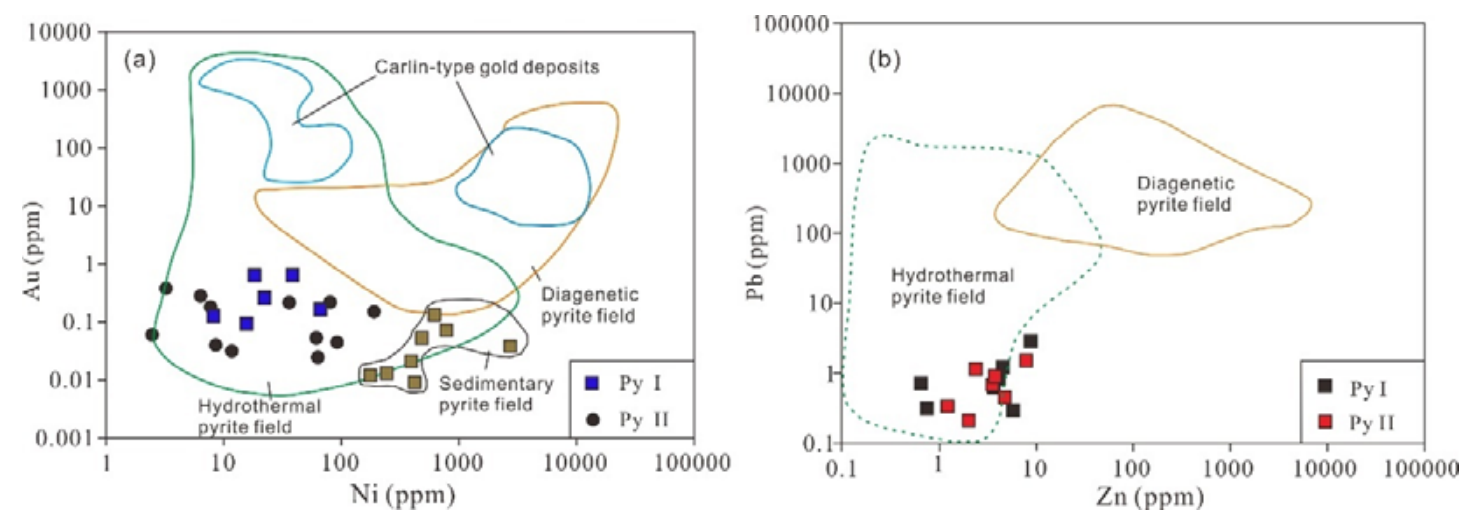

Figure 8. Ni vs. Au diagram (a) and $\mathrm{Zn}$ vs. Pb diagram (b) for pyrite from massive and lamellar ores of the Dongguashan copper (gold) deposit (after Reference [6]). Data of sedimentary pyrite are from Reference [54].

In general, the trace element compositions of pyrite and pyrrhotite hosted in the stratiform and lamellar orebodies show that mineralization is closely related to magmatic-hydrothermal activities. Magmatic-hydrothermal fluid fills along the interformational fracture zones and comes in contact with the surrounding rock to generate chalcopyrite, magnetite, pyrite, pyrrhotite, garnet, diopside and epidote, which forms the stratiform orebody. The retrograde alteration of magnesian skarn minerals forms serpentine, talc, chalcopyrite, pyrite and pyrrhotite, and later forms the lamellar orebody by the self-organized developed of minerals [28]. 


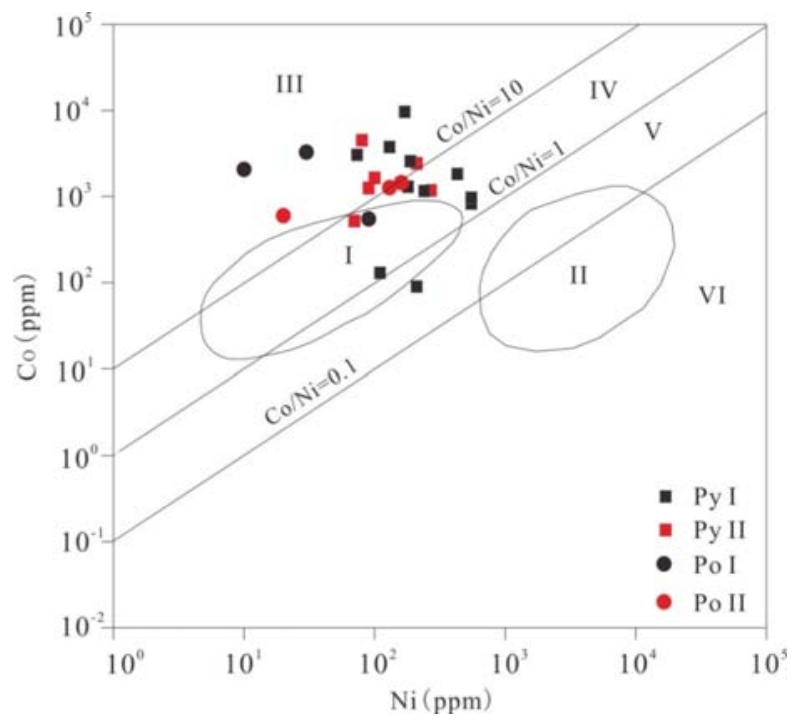

Figure 9. Ni vs. Co diagrams for pyrite and pyrrhotite from massive and lamellar ores of the Dongguashan copper (gold) deposit (References [70,72]). I: deposit related to magmatic-hydrothermal solutions; II: Cu-Ni sulfide deposit; III, IV: magmatic and hydrothermal fields; V, VI: sedimentary and sedimentary-reformed field (Note: I, II stand for the data of pyrrhotite; III-VI regions stand for the data of pyrite).

\section{Conclusions}

The major and trace element compositions indicate that the ore-forming materials are principally originated from the magmatism. Pyrite and pyrrhotite hosted in the stratiform and lamellar orebodies are magmatic-hydrothermal origins. The ore-forming conditions are medium-high temperature, high sulfur fugacity and medium-shallow depth. Therefore, the Dongguashan copper (gold) deposit should be a stratabound skarn-type ore deposit associated with magma intrusion activity during the Yanshanian Period.

Author Contributions: Z.L., Y.S., and Q.L. conceived and designed the experiments; Z.L., N.L. and C.W. performed the experiments; all authors wrote the paper.

Funding: This research was funded by National Natural Science Foundation of China grant number (41702078) and Open Topic of Hunan Key Laboratory of Land Resources Evaluation and Utilization grant number (SYS-ZX-201803).

Acknowledgments: This work was supported by the National Natural Science Foundation of China (Grant No. 41702078), the Open Topic of Hunan Key Laboratory of Land Resources Evaluation and Utilization (Grant No. SYS-ZX-201803) and the General Financial Grant from the China Postdoctoral Science Foundation (Grant No. 2017M622596). We are grateful to anonymous reviewers for their critical and constructive reviews, which greatly improved the paper.

Conflicts of Interest: The authors declare no conflicts of interest. 
Appendix A. Electron-Probe Microanalyses (EPMA) Data of Pyrite of the Dongguashan Deposit (wt.\%)

\begin{tabular}{|c|c|c|c|c|c|c|c|c|c|c|c|c|c|c|c|}
\hline Sample & $S$ & $\mathrm{Fe}$ & As & Co & $\mathbf{N i}$ & $\mathrm{Sb}$ & Ag & $\mathrm{Au}$ & Total & $\mathrm{S} / \mathrm{Fe}$ & $\mathrm{Co} / \mathrm{Ni}$ & $\mathrm{Au} / \mathrm{Ag}$ & $\mathrm{Fe} /(\mathrm{S}+\mathrm{As})$ & As/Au & $\mathrm{Sb} / \mathrm{Au}$ \\
\hline \multicolumn{16}{|c|}{ Py I } \\
\hline DGS1-9 & 53.47 & 47.83 & - & 0.12 & 0.02 & 0.01 & 0.02 & 0.14 & 101.61 & 1.95 & 6.00 & 8.94 & 0.89 & - & 0.07 \\
\hline DGS1-9 & 53.51 & 47.68 & 0.01 & 0.18 & - & - & 0.03 & 0.02 & 101.42 & 1.95 & - & 0.73 & 0.89 & 0.50 & \\
\hline DGS1-9 & 52.82 & 47.95 & - & 0.13 & 0.02 & - & - & - & 100.91 & 1.92 & 6.50 & - & 0.91 & & \\
\hline DGS1-9 & 51.35 & 47.50 & - & 0.32 & - & - & - & - & 99.16 & 1.88 & - & - & 0.92 & & \\
\hline DGS1-9 & 51.27 & 47.65 & - & 0.16 & - & - & - & 0.04 & 99.12 & 1.87 & - & - & 0.93 & & \\
\hline DGS1-9 & 51.56 & 47.51 & - & 0.40 & - & 0.01 & 0.04 & 0.06 & 99.58 & 1.89 & - & 1.44 & 0.92 & & 0.17 \\
\hline DGS1-9 & 51.60 & 47.65 & - & 0.18 & 0.04 & - & - & - & 99.47 & 1.89 & 4.25 & - & 0.92 & & \\
\hline DGS1-9 & 53.90 & 47.36 & - & 0.38 & 0.01 & - & - & 0.09 & 101.74 & 1.98 & 38.00 & - & 0.88 & & \\
\hline DGS1-9 & 53.03 & 46.99 & - & - & 0.01 & - & - & - & 100.03 & 1.97 & - & - & 0.89 & & \\
\hline DGS1-9 & 53.65 & 46.65 & - & 0.45 & - & - & - & - & 100.75 & 2.00 & - & - & 0.87 & & \\
\hline DGS1-9 & 54.04 & 46.64 & - & - & 0.01 & - & 0.02 & - & 100.71 & 2.02 & - & - & 0.86 & & \\
\hline DGS1-9 & 52.72 & 47.41 & 0.01 & 0.26 & 0.02 & 0.01 & 0.02 & 0.08 & 100.39 & 1.94 & 13.00 & 3.78 & 0.90 & 0.13 & 0.13 \\
\hline DGS3-4 & 53.50 & 48.03 & - & 0.04 & - & - & 0.05 & 0.07 & 101.69 & 1.94 & - & 1.41 & 0.90 & & \\
\hline DGS3-4 & 53.28 & 47.56 & - & - & - & - & - & - & 100.84 & 1.95 & - & - & 0.89 & & \\
\hline DGS3-4 & 51.19 & 45.56 & - & 0.96 & 0.02 & 1.35 & - & 0.22 & 99.30 & 1.96 & 48.00 & - & 0.89 & & 6.14 \\
\hline DGS3-4 & 50.98 & 45.88 & - & 0.06 & - & 0.01 & 0.29 & 0.04 & 97.26 & 1.93 & & 0.13 & 0.90 & & 0.25 \\
\hline DGS3-4 & 51.69 & 46.02 & 0.01 & 0.07 & - & - & - & 0.17 & 97.94 & 1.96 & - & - & 0.89 & 0.59 & \\
\hline DGS3-4 & 54.21 & 47.44 & - & 0.13 & - & - & 0.02 & - & 101.79 & 1.99 & - & - & 0.88 & & \\
\hline DGS3-4 & 54.17 & 47.54 & - & - & - & - & - & 0.13 & 101.84 & 1.98 & - & - & 0.88 & & \\
\hline DGS3-4 & 54.22 & 47.70 & - & - & - & - & 0.02 & - & 101.94 & 1.98 & - & - & 0.88 & & \\
\hline DGS3-4 & 52.74 & 46.69 & 0.01 & 0.31 & 0.01 & 0.68 & 0.11 & 0.14 & 100.01 & 1.97 & 31.00 & 1.26 & 0.89 & 0.71 & 4.86 \\
\hline DGS3-5 & 53.67 & 45.98 & 0.66 & 0.01 & 0.01 & - & 0.05 & 0.04 & 100.43 & 2.03 & 1.00 & 0.90 & 0.85 & 16.50 & \\
\hline DGS3-5 & 53.61 & 45.72 & 0.82 & 0.01 & 0.02 & - & - & 0.04 & 100.22 & 2.04 & 0.50 & - & 0.84 & 20.50 & \\
\hline DGS3-6 & 54.78 & 46.84 & 0.01 & 0.10 & 0.06 & - & 0.03 & - & 101.81 & 2.04 & 1.76 & - & 0.85 & & \\
\hline DGS3-6 & 53.75 & 45.59 & - & 0.07 & - & - & 0.06 & 0.12 & 99.59 & 2.05 & - & 1.87 & 0.85 & & \\
\hline DGS3-6 & 54.26 & 46.22 & 0.01 & 0.08 & 0.06 & - & 0.05 & 0.12 & 100.70 & 2.04 & 1.33 & 2.62 & 0.85 & 0.08 & \\
\hline DGS3-6 & 53.83 & 47.09 & - & - & - & - & 0.03 & - & 100.94 & 1.99 & - & - & 0.87 & & \\
\hline DGS3-6 & 53.83 & 47.09 & - & - & - & - & 0.03 & - & 100.94 & 1.99 & - & - & 0.87 & & \\
\hline Mean (30) & 53.07 & 47.02 & 0.19 & 0.21 & 0.02 & 0.31 & 0.05 & 0.09 & 100.43 & 1.97 & 10.50 & 2.74 & 0.89 & 2.11 & 3.44 \\
\hline
\end{tabular}




\begin{tabular}{|c|c|c|c|c|c|c|c|c|c|c|c|c|c|c|c|}
\hline Sample & $S$ & $\mathrm{Fe}$ & As & Co & $\mathbf{N i}$ & $\mathrm{Sb}$ & Ag & $\mathrm{Au}$ & Total & $\mathrm{S} / \mathrm{Fe}$ (at) & $\mathrm{Co} / \mathrm{Ni}$ & $\mathrm{Au} / \mathrm{Ag}$ & $\mathrm{Fe} /(\mathrm{S}+\mathrm{As})$ & $\mathrm{As} / \mathrm{Au}$ & $\mathrm{Sb} / \mathrm{Au}$ \\
\hline \multicolumn{16}{|c|}{ Py II } \\
\hline DGS1-7 & 53.69 & 46.71 & - & 0.45 & 0.01 & 0.01 & 0.02 & 0.05 & 100.92 & 2.00 & 45.00 & 3.19 & 0.87 & & 0.20 \\
\hline DGS1-7 & 53.80 & 46.96 & - & 0.05 & 0.01 & 0.01 & 0.02 & 0.12 & 100.95 & 2.00 & 5.00 & 5.57 & 0.87 & & 0.08 \\
\hline DGS1-7 & 53.95 & 46.89 & - & 0.12 & 0.03 & - & - & 0.18 & 101.17 & 2.00 & 4.00 & - & 0.87 & & \\
\hline DGS1-7 & 53.67 & 47.32 & - & - & - & - & - & - & 101.01 & 1.98 & - & - & 0.88 & & \\
\hline DGS1-7 & 51.61 & 47.64 & - & 0.04 & - & - & 0.06 & - & 99.36 & 1.89 & - & - & 0.92 & & \\
\hline DGS1-7 & 51.82 & 47.39 & - & 0.27 & - & - & 0.09 & - & 99.56 & 1.90 & - & - & 0.91 & & \\
\hline DGS1-7 & 51.04 & 47.62 & - & 0.09 & - & - & - & - & 98.75 & 1.87 & - & - & 0.93 & & \\
\hline DGS1-7 & 51.14 & 47.27 & - & 0.28 & - & 0.02 & - & - & 98.70 & 1.88 & - & - & 0.92 & & \\
\hline DGS1-7 & 50.94 & 47.17 & - & 0.16 & - & - & 0.01 & 0.10 & 98.38 & 1.88 & - & 7.31 & 0.93 & & \\
\hline DGS1-7 & 50.52 & 47.48 & - & 0.03 & - & - & 0.01 & 0.07 & 98.10 & 1.85 & - & 5.92 & 0.94 & & \\
\hline DGS1-7 & 52.22 & 47.24 & - & 0.16 & 0.01 & 0.01 & 0.03 & 0.10 & 99.69 & 1.92 & 16.00 & 3.40 & 0.90 & & 0.10 \\
\hline DGS4-17 & 53.98 & 48.04 & - & - & - & - & - & 0.08 & 102.10 & 1.96 & - & - & 0.89 & & \\
\hline DGS4-17 & 54.04 & 47.32 & 0.02 & 0.24 & 0.02 & 0.01 & - & 0.07 & 101.72 & 1.99 & 12.0 & - & 0.88 & 0.29 & 0.14 \\
\hline DGS4-17 & 54.01 & 47.68 & - & 0.24 & 0.02 & 0.01 & - & 0.08 & 101.91 & 1.97 & 12.0 & - & 0.88 & & 0.13 \\
\hline DGS5-16 & 53.49 & 47.14 & 0.04 & 0.22 & - & - & 0.01 & 0.20 & 100.97 & 1.98 & - & 22.00 & 0.88 & 0.20 & \\
\hline DGS5-16 & 53.15 & 46.56 & 0.04 & 0.34 & - & - & 0.01 & 0.20 & 100.29 & 1.99 & - & 33.00 & 0.88 & 0.20 & \\
\hline DGS5-16 & 53.83 & 47.72 & - & 0.09 & - & - & 0.01 & - & 101.66 & 1.96 & - & - & 0.89 & & \\
\hline DGS7 & 53.22 & 47.73 & - & 0.02 & - & - & - & 0.11 & 101.08 & 1.94 & - & - & 0.90 & & \\
\hline DGS7 & 53.89 & 47.27 & - & - & - & 0.03 & - & 0.05 & 101.24 & 1.99 & - & - & 0.88 & & 0.60 \\
\hline DGS7 & 53.56 & 47.50 & - & 0.02 & - & 0.03 & - & 0.08 & 101.16 & 1.96 & - & - & 0.89 & & 0.38 \\
\hline DGS19-1 & 53.11 & 47.16 & - & 0.05 & 0.01 & - & 0.02 & - & 100.35 & 1.96 & 5.00 & - & 0.89 & & \\
\hline DGS19-1 & 53.50 & 47.37 & 0.61 & 0.32 & - & - & - & 0.05 & 101.85 & 1.97 & - & - & 0.88 & 12.20 & \\
\hline DGS19-1 & 53.38 & 47.15 & - & - & - & 0.02 & - & - & 100.54 & 1.97 & - & - & 0.88 & & \\
\hline DGS19-1 & 53.77 & 47.26 & - & - & 0.01 & - & - & - & 101.05 & 1.98 & - & - & 0.88 & & \\
\hline DGS19-1 & 53.44 & 47.23 & 0.61 & 0.13 & 0.01 & 0.02 & 0.02 & 0.03 & 100.95 & 1.97 & 13.00 & 1.32 & 0.87 & 20.33 & 0.67 \\
\hline Mean (25) & 52.99 & 47.31 & 0.26 & 0.16 & 0.01 & 0.01 & 0.03 & 0.09 & 100.54 & 1.95 & 16.00 & 10.21 & 0.89 & 2.89 & 0.11 \\
\hline
\end{tabular}


Appendix B. EPMA Data of Pyrrhotite of the Dongguashan Deposit (wt.\%)

\begin{tabular}{|c|c|c|c|c|c|c|c|c|c|c|c|c|}
\hline Sample & $S$ & $\mathrm{Fe}$ & As & Ag & Co & $\mathbf{A u}$ & $\mathrm{Cu}$ & $\mathrm{Zn}$ & $\mathrm{Sb}$ & Total & Fe (at.\%) & $\mathrm{Au} / \mathrm{Ag}$ \\
\hline \multicolumn{13}{|c|}{ Po I } \\
\hline \multirow{2}{*}{ DGS17 } & 39.96 & 61.66 & 0.07 & 0.02 & 0.06 & - & 0.09 & 0.03 & 0.01 & 101.9 & 46.98 & - \\
\hline & 39.91 & 62.00 & 0.06 & - & 0.07 & 0.03 & 0.12 & 0.09 & - & 102.28 & 47.15 & - \\
\hline \multirow{5}{*}{ DGS3-5 } & 38.86 & 59.97 & 0.01 & - & 0.06 & - & - & - & - & 98.9 & 46.98 & - \\
\hline & 38.38 & 60.47 & - & - & 0.22 & - & - & - & - & 99.07 & 47.50 & - \\
\hline & 38.74 & 59.82 & - & 0.04 & 0.00 & 0.07 & - & - & - & 98.67 & 46.99 & 1.94 \\
\hline & 38.65 & 60.45 & 0.03 & 0.04 & 0.16 & 0.17 & - & - & - & 99.5 & 47.32 & 4.18 \\
\hline & 38.79 & 60.53 & - & - & 0.33 & 0.06 & - & - & - & 99.71 & 47.25 & \\
\hline \multirow[t]{3}{*}{ DGS5-9 } & 39.08 & 60.73 & - & - & 0.21 & 0.07 & - & - & - & 100.09 & 47.15 & - \\
\hline & 37.19 & 60.64 & 0.10 & 0.01 & - & - & - & - & 0.01 & 97.95 & 48.35 & - \\
\hline & 38.98 & 60.43 & - & - & - & - & - & - & - & 99.41 & 47.10 & - \\
\hline Mean (10) & 38.85 & 60.71 & 0.05 & 0.02 & 0.16 & 0.08 & 0.10 & 0.06 & 0.01 & 99.748 & 47.28 & 3.06 \\
\hline Sample & $\mathrm{s}$ & $\mathrm{Fe}$ & As & $\mathrm{Ag}$ & Co & $\mathbf{A u}$ & $\mathrm{Cu}$ & $\mathrm{Zn}$ & $\mathrm{Sb}$ & Total & Fe (at.\%) & $\mathrm{Au} / \mathrm{Ag}$ \\
\hline \multicolumn{13}{|c|}{ Po II } \\
\hline \multirow{7}{*}{ DK3-14 } & 38.84 & 57.90 & 0.07 & 0.02 & 0.11 & 0.07 & 0.08 & 0.11 & 0.03 & 97.23 & 46.12 & 4.87 \\
\hline & 39.31 & 58.79 & 0.09 & 0.04 & 0.06 & - & - & - & - & 98.29 & 46.20 & - \\
\hline & 39.21 & 59.64 & 0.13 & - & 0.13 & - & - & - & - & 99.11 & 46.62 & - \\
\hline & 38.64 & 59.00 & 0.10 & - & 0.13 & 0.04 & - & 0.05 & - & 97.96 & 46.71 & - \\
\hline & 39.80 & 60.31 & 0.11 & - & 0.09 & - & - & - & - & 100.31 & 46.53 & - \\
\hline & 39.80 & 60.16 & 0.16 & - & 0.09 & 0.08 & - & - & 0.02 & 100.31 & 46.46 & - \\
\hline & 39.41 & 59.52 & 0.08 & - & 0.11 & - & 0.02 & 0.05 & - & 99.19 & 46.44 & - \\
\hline \multirow{7}{*}{ DK3-16 } & 39.23 & 60.70 & 0.07 & - & 0.09 & 0.12 & - & 0.07 & - & 100.28 & 47.05 & - \\
\hline & 40.05 & 61.12 & 0.08 & - & 0.12 & - & 0.01 & 0.10 & - & 101.48 & 46.70 & - \\
\hline & 39.80 & 60.79 & 0.08 & - & 0.12 & - & 0.03 & 0.05 & - & 100.87 & 46.72 & - \\
\hline & 40.03 & 60.28 & 0.07 & 0.02 & 0.11 & 0.02 & 0.02 & - & - & 100.55 & 46.37 & 1.25 \\
\hline & 39.94 & 59.47 & 0.06 & - & 0.15 & 0.06 & 0.05 & - & 0.03 & 99.76 & 46.09 & - \\
\hline & 40.01 & 59.92 & 0.09 & - & 0.10 & - & 0.03 & 0.06 & - & 100.21 & 46.23 & - \\
\hline & 39.64 & 61.03 & 0.06 & - & 0.14 & - & - & 0.01 & - & 100.88 & 46.92 & - \\
\hline Mean (14) & 39.55 & 59.90 & 0.09 & 0.027 & 0.11 & 0.06 & 0.03 & 0.05 & 0.01 & 99.745 & 46.52 & 3.06 \\
\hline
\end{tabular}


Appendix C. Laser Ablation Inductively Coupled Plasma Mass Spectrometry (LA-ICP-MS) Data of Pyrite of the Dongguashan Deposit (ppm)

\begin{tabular}{|c|c|c|c|c|c|c|c|c|c|c|c|c|c|c|}
\hline Sample & $\mathbf{W}$ & Sn & Mo & $\mathbf{B i}$ & V & Mn & $\mathrm{Cu}$ & $\mathrm{Pb}$ & $\mathrm{Zn}$ & Se & $\mathrm{Sb}$ & $\mathrm{Te}$ & $\mathrm{Hg}$ & Cd \\
\hline \multicolumn{15}{|c|}{ Py I } \\
\hline DGS1-9 & - & - & 0.29 & 1.10 & 0.03 & 0.58 & 1.19 & 0.28 & 10.47 & 67.54 & - & - & - & 2.47 \\
\hline DGS1-9 & - & - & 2.30 & 0.07 & 0.11 & 0.59 & 0.04 & - & 5.68 & 75.77 & - & - & - & 2.75 \\
\hline DGS3 & 0.35 & 0.25 & - & 0.03 & 0.27 & 1.01 & 20.30 & - & 4.25 & 12.40 & - & - & 1.29 & 2.36 \\
\hline DGS3 & 0.07 & 0.20 & 0.21 & 0.38 & 0.04 & 0.76 & 0.69 & 0.49 & - & 3.49 & 0.11 & - & 0.60 & 0.40 \\
\hline DGS3-4 & 0.14 & 0.54 & - & 1.51 & 0.60 & 12.48 & 6.31 & 2.72 & 15.83 & 62.48 & 0.28 & 4.51 & - & 0.87 \\
\hline DGS3-4 & 0.48 & 0.14 & 0.20 & 0.13 & 0.01 & 2.24 & 6.13 & - & 9.10 & 75.39 & - & 2.42 & 0.40 & 0.67 \\
\hline DGS3-5 & - & 0.25 & - & 0.61 & 0.04 & 2.83 & 461.81 & 1.16 & 8.19 & 32.02 & - & - & 0.14 & 0.36 \\
\hline DGS3-5 & - & - & - & 0.37 & 0.02 & 1.17 & 374.87 & 0.30 & 1.20 & 17.50 & 0.03 & - & - & 0.20 \\
\hline DGS3-6 & - & - & - & - & - & - & 1.55 & - & 11.89 & 22.81 & 0.17 & - & - & 1.25 \\
\hline DGS3-6 & 0.23 & - & - & 0.26 & 0.15 & - & 1.75 & 0.68 & 1.04 & 42.36 & 0.14 & 2.90 & - & 1.64 \\
\hline Mean (11) & 0.30 & 0.27 & 0.62 & 0.49 & 0.13 & 2.46 & 79.65 & 0.78 & 7.42 & 41.80 & 0.11 & 3.00 & 0.61 & 1.25 \\
\hline Sample & W & Sn & Mo & $\mathbf{B i}$ & $\mathrm{V}$ & Mn & $\mathrm{Cu}$ & $\mathrm{Pb}$ & $\mathrm{Zn}$ & Se & $\mathrm{Sb}$ & $\mathrm{Te}$ & $\mathrm{Hg}$ & $\mathrm{Cd}$ \\
\hline \multicolumn{15}{|c|}{ Py II } \\
\hline DGS1-7 & - & 0.03 & - & 0.09 & - & - & 4.32 & 0.08 & 7.65 & 47.71 & - & 1.41 & 1.34 & 0.39 \\
\hline DGS1-7 & 0.31 & - & - & 0.09 & - & 0.08 & 4.07 & 0.43 & 8.59 & 60.52 & - & 5.80 & 1.12 & 1.97 \\
\hline DGS4-17 & - & 0.15 & 0.05 & 0.55 & 0.15 & 53.27 & 2.67 & 1.44 & 14.27 & 14.44 & 0.25 & - & - & 1.98 \\
\hline DGS4-17 & - & 0.28 & - & 0.30 & 0.05 & 0.04 & 1.02 & - & 2.60 & 50.05 & 0.09 & 8.43 & 0.17 & 0.20 \\
\hline DGS5-16 & - & - & 0.25 & 0.27 & 0.18 & - & 4.07 & - & 7.05 & 57.92 & - & 1.96 & 0.45 & 2.54 \\
\hline DGS5-16 & 9.45 & 1.03 & 0.12 & 2.55 & 8.55 & 19.81 & 1311.82 & 1.40 & - & 83.70 & - & 5.48 & - & 2.71 \\
\hline DGS5-16 & - & - & 0.33 & 1.03 & 2.57 & 8.88 & 475.25 & - & - & 7.83 & - & 1.10 & - & 1.43 \\
\hline DGS7 & 0.45 & 0.18 & 0.12 & 0.45 & 0.06 & 0.06 & 67.04 & 0.86 & 6.80 & 13.07 & 0.70 & 0.69 & 1.05 & - \\
\hline DGS7 & 0.02 & 0.06 & - & 0.16 & 0.10 & 0.59 & 23.86 & 1.09 & 4.32 & 11.25 & 0.45 & 1.52 & 0.88 & 0.23 \\
\hline DGS7 & 1.00 & - & 0.26 & 0.22 & 0.22 & 129.07 & 26.29 & 0.32 & 1.96 & 8.88 & 15.81 & 0.58 & 0.66 & 0.07 \\
\hline DGS7 & 3.03 & 0.14 & 0.32 & 0.08 & - & - & 3.19 & 0.20 & 3.22 & 10.03 & 6.70 & 0.98 & 0.69 & 0.06 \\
\hline DGS7 & 0.02 & - & 0.22 & 0.56 & 0.08 & 0.39 & 3.41 & 0.05 & 1.63 & 88.41 & - & 0.22 & 0.30 & 0.05 \\
\hline Mean (13) & 1.81 & 0.26 & 0.24 & 0.62 & 1.20 & 21.57 & 191.86 & 0.65 & 6.39 & 34.56 & 4.00 & 2.56 & 0.77 & 1.13 \\
\hline
\end{tabular}


Appendix D. LA-ICP-MS Data of Pyrrhotite of the Dongguashan Deposit (ppm)

\begin{tabular}{|c|c|c|c|c|c|c|c|c|c|c|c|c|}
\hline Sample & $\mathbf{W}$ & Sn & Mo & Co & $\mathrm{Ni}$ & $\mathrm{Cu}$ & $\mathrm{Pb}$ & $\mathrm{Zn}$ & As & Se & Ag & $\mathrm{Co} / \mathrm{Ni}$ \\
\hline \multicolumn{13}{|c|}{ Po I } \\
\hline DGS2-7 & 1.82 & 1.13 & 0.68 & 32.81 & 20.84 & $15,806.73$ & 4.47 & 29.20 & - & 81.71 & 4.03 & 1.57 \\
\hline DGS2-8 & - & 1.16 & 0.14 & 0.20 & 0.13 & - & - & - & 1.49 & 47.21 & 0.36 & 1.55 \\
\hline DGS2-9 & 1.39 & - & - & 2.05 & 1.21 & 15.43 & 0.71 & - & 1.25 & 6.16 & 1.13 & 1.70 \\
\hline DGS2-10 & - & 2.43 & - & 14.44 & 1.00 & 17.07 & 3.54 & 52.04 & - & 59.40 & - & 14.45 \\
\hline DGS2-11 & 0.87 & 0.86 & - & 3.91 & 2.13 & 6.30 & 4.72 & 19.52 & 1.51 & 67.62 & 1.97 & 1.84 \\
\hline Mean (5) & 1.36 & 1.40 & 0.40 & 10.70 & 5.06 & 3961.38 & 3.36 & 33.58 & 1.42 & 52.42 & 1.87 & 4.22 \\
\hline Sample & W & Sn & Mo & Co & $\mathbf{N i}$ & $\mathrm{Cu}$ & $\mathrm{Pb}$ & $\mathrm{Zn}$ & As & Se & $\mathrm{Ag}$ & $\mathrm{Co} / \mathrm{Ni}$ \\
\hline \multicolumn{13}{|c|}{ Po II } \\
\hline DGS7 & 3.22 & - & 0.67 & 1.93 & 1.42 & 29.03 & 1.06 & 56.07 & 7.22 & - & 1.27 & 1.36 \\
\hline DGS7 & 4.32 & 2.35 & 0.32 & 1.23 & 1.21 & 3576.91 & 3.62 & 55.98 & 12.03 & 17.66 & 1.61 & 1.02 \\
\hline Mean (2) & 3.77 & 2.30 & 0.50 & 1.58 & 1.32 & 1802.97 & 2.34 & 56.03 & 9.63 & 17.70 & 1.44 & 1.19 \\
\hline
\end{tabular}

"_" below detection limits. 


\section{References}

1. Song, X.X.; Zhang, J.K. Minor elements in pyrites of various genetic types from China. Bull. Inst. Miner. Depos. Chin. Acad. Geol. Sci. 1986, 2, 166-175. (In Chinese)

2. Leng, C.B. Genesis of Hongshan $\mathrm{Cu}$ polymetallic large deposit in the Zhongdian area, NW Yunnan: Constraints from LA-ICPMS trace elements of pyritie and pyrrhotite. Earth Sci. Front. 2017, 24, 162-175. (In Chinese)

3. Henley, R.W. Chemical structure of geothermal systems: Fluid mineral equiliria in hydrothermal systems. Rev. Econ. 1984, 1, 9-28.

4. Wilson, S.A.; Ridley, W.I.; Koenig, A.E. Development of sulfide calibration standards for the laser ablation inductively-coupled plasma mass spectrometry technique. J. Anal. At. Spectrom. 2002, 17, 406-409. [CrossRef]

5. Large, R.R.; Maslennikov, V.V.; Robert, F.; Danyushevsky, L.V.; Chang, Z. Multistage sedimentary and metamorphic origin of pyrite and gold in the Giant Sukhoi Log Deposit, Lena gold province. Russ. Econ. Geol. 2007, 102, 1233-1267. [CrossRef]

6. Large, R.R.; Danyushevsky, L.; Hollit, C.; Maslennikov, V.; Meffre, S. Gold and trace element zonation in pyrite using a laser imaging technique: Implications for the timing of gold in Orogenic and Carlin-style sediment-hosted deposits. Econ. Geol. 2009, 104, 635-668. [CrossRef]

7. Zhou, T.F.; Zhang, L.J.; Yuan, F.; Fan, Y.; Cook, D.R. LA-ICP-MS in situ trace element analysis of pyrite from the Xinqiao Cu-Au-S deposit in Tongling, Anhui, and its constrains on the ore genesis. Earth Sci. Front. 2010, 2, 306-319. (In Chinese)

8. Shao, Y.J.; Wang, W.S.; Liu, Q.Q.; Zhang, Y. Trace element analysis of pyrite from the Zhengchong gold deposit, Northeast Hunan Province, China: Implications for the ore-forming process. Minerals 2018, 8, 262. [CrossRef]

9. Dupuis, C.; Beaudoin, G. Discriminant diagrams for iron oxide trace element fingerprinting of mineral deposit types. Miner. Depos. 2011, 4, 319-335. [CrossRef]

10. Chen, W.T.; Zhou, M.F.; Cao, J.F.; Hu, R. Geochemistry of magnetite from Proterozoic Fe-Cu deposits in the Kangdian metallogenic province, SW China. Miner. Depos. 2015, 7, 795-809. [CrossRef]

11. Chang, Y.F.; Liu, X.G. On strata-bound skam deposits. Miner. Depos. 1983, 2, 11-20. (In Chinese)

12. Chu, G.Z. Bedding slipping structures control on the "multistory" ore deposits, in the Shizishan oredield of Anhui. Geoscience 1992, 4, 504-513.

13. Huang, X.C.; Chu, G.Z. Multistory metallogenic model of the Shizishan oredield in Tongling, Anhui Province. Miner. Depos. 1993, 3, 221-230.

14. Tang, Y.C.; Wu, C.Y.; Chu, G.Z.; Xing, F.M.; Wang, Y.M.; Cao, F.Y.; Chang, Y.F. Geology of Copper-Gold Polymetallic Deposits in the along-Changjiang Area of Anhui Province; Geological Publishing House: Beijing, China, 1998; pp. 1-351. (In Chinese)

15. Pan, Y.M.; Dong, P. The Lower Changjiang (Yangzi/Yangtze River) metallogenic belt, East China: Intrusionand wall rock-hosted $\mathrm{Cu}-\mathrm{Fe}-\mathrm{Au}, \mathrm{Mo}, \mathrm{Zn}, \mathrm{Pb}, \mathrm{Ag}$ de-posits. Ore Geol. Rev. 1999, 15, 177-242. [CrossRef]

16. Mao, J.W.; Xie, G.Q.; Duan, C.; Pirajno, F.; Ishiyama, D.; Chen, Y.C. A tectono-genetic model for porphyry-skarn-stratabound $\mathrm{Cu}-\mathrm{Au}-\mathrm{Mo}-\mathrm{Fe}$ and magnetite-apatite deposits along the Middle-Lower Yangtze River Valley, Eastern China. Ore Geol. Rev. 2011, 43, 294-314. [CrossRef]

17. Liu, Y.Q.; Liu, Z.L.; Yang, C.X. Stable isotope studies of the Dongguashan copper deposit in Tongling prefecture, Anhui Province. Bull. Inst. Miner. Depos. Chin. Acad. Geol. Sci. 1984, 1, 70-101. (In Chinese)

18. Xu, W.Y.; Yang, Z.S.; Meng, Y.F.; Zeng, P.S.; Shi, D.N.; Tian, S.H.; Li, H.Y. Genetic model and dynamic migration of ore-forming fluids in carboniferous exhalation-sedimentary massive sulfide deposits of Tongling district, Anhui Province. Miner. Depos. 2004, 23, 353-364. (In Chinese)

19. Li, H.Y.; Yang, Q.R.; Li, Y.J.; Hou, Z.Q.; Yang, Z.S.; Meng, Y.F. Geochemical characteristics of the Dongguashan copper deposit in Anhui Province. Acta Geosci. Sin. 2006, 27, 551-556. (In Chinese)

20. Xu, Z.W.; Lu, X.C.; Gao, G.; Fang, C.Q.; Wang, Y.J.; Yang, X.N.; Jiang, S.Y.; Chen, B.G. Isotope geochemistry and mineralization in the Dongguashan diplogenetic stratified copper deposit, Tongling area. Geol. Rev. 2007, 53, 44-51. (In Chinese)

21. Lu, J.J.; Guo, W.M.; Chen, W.F.; Jiang, S.Y.; Li, J.; Yan, X.R.; Xu, Z.W. A metallogenic model for the Dongguashan Cu-Au deposit of Tongling, Anhui Province. Acta Petrol. Sin. 2008, 24, 1857-1864. (In Chinese) 
22. Guo, W.M.; Lu, J.J.; Zhang, R.Q.; Xu, Z.W. Ore textures and genetic significance of pyrrhotite from Dongguashan ore deposit in Tongling area, Anhui Province. Miner. Depos. 2010, 29, 405-414. (In Chinese)

23. Xu, X.C.; Yin, T.; Lou, J.W.; Lu, S.M.; Xie, Q.Q.; Zhu, P.L. Origin of Dongguashan stratabound Cu-Au skarn deposit in Tongling: Restraints of sulfur isotope. Acta Petrol. Sin. 2010, 26, 2739-2750. (In Chinese)

24. Liu, Z.F.; Shao, Y.J.; Zhou, X.; Zhang, Y.; Zhou, G.B. Characteristics of ore-forming fluids and metallogenic process of Dongguashan copper (gold) deposit in Anhui Province. Miner. Depos. 2014, 33, 639-650. (In Chinese)

25. Liu, Z.F.; Shao, Y.J.; Zhou, X.; Zhang, Y.; Zhou, G.B. Hydrogen, oxygen, sulfur and lead isotope composition tracing for the ore-forming material source of Dongguashan copper (gold) deposit in Tongling, Anhui Province. Acta Petrol. Sin. 2014, 30, 199-208. (In Chinese)

26. Cao, Y.; Du, Y.S.; Pang, Z.S.; Ren, C.L.; Du, Y.L.; Xiao, F.Q.; Zhou, G.B.; Chen, L.J. Sulfide zonal texture and its geological significance of ores from the Dongguashan copper (gold) deposit in Tongling, Anhui Province, China. Acta Petrol. Sin. 2016, 32, 334-335. (In Chinese)

27. Chang, Y.F.; Liu, X.P.; Wu, C.Y. The Copper-Iron Belt of the Lower and Middle Reaches of the Changiiang River; Geological Publishing House: Beijing, China, 1991; pp. 1-379. (In Chinese)

28. Mao, J.W.; Shao, Y.J.; Xie, G.Q.; Zhang, J.D.; Chen, Y.C. Mineral deposit model for porphyry-skarn polymetallic copper deposits in Tongling ore dense district of Middle-Lower Yangtze Valley metallogenic belt. Miner. Depos. 2009, 28, 209-219. (In Chinese)

29. Xu, X.C.; Lu, S.M.; Xie, Q.Q.; Lou, J.W.; Chu, P.L. Trace element geochemical characteristics of fluid inclusions of Anhui Province, and their geological implications. Acta Petrol. Sin. 2008, 8, 1865-1874. (In Chinese)

30. Guo, W.M.; Lu, J.J.; Jiang, S.Y.; Zhang, R.Q.; Zhao, Z.J. Chronology, Hf isotopes, geochemistry, and petrogenesis of the magmatic rocks in the Shizishan ore field of Tongling, Anhui Province. Sci. China Earth Sci. 2013, 6, 993-1013. [CrossRef]

31. Gu, L.X.; Zaw, K.; Hu, W.X.; Zhang, K.J.; Ni, P.; He, J.X.; Xu, Y.T.; Lu, J.J.; Lin, C.M. Distinctive features of Late Palaeozoic massive sulphide deposits in South China. Ore Geol. Rev. 2007, 31, 107-138. [CrossRef]

32. Zeng, P.S.; Pei, R.F.; Hou, Z.Q.; Meng, Y.F.; Yang, Z.S.; Tian, S.H.; Xu, W.Y.; Wang, X.C. The Dongguashan deposit in the Tongling mineralization cluster Area, Anhui: A large-sized superimposition type copper deposit. Acta Geol. Sin. 2005, 79, 106-131. (In Chinese)

33. Liu, J.H.; Li, H.; Xu, Z.W.; Lu, X.C.; Liu, S.M.; Nie, G.P. Metallogenic geological settings and genesis of Dongguashan stratified cooper deposit. J. Geol. 2009, 3, 133-137. (In Chinese)

34. Guo, W.M.; Lu, J.J.; Zhang, R.Q.; Zhao, Z.J.; Xu, Z.W. The superimposed mineralization of the Dongguashan $\mathrm{Cu}$ deposit in Tongling Area, Anhui Province: Evidence from the ore texture. Acta Geol. Sin. 2011, 85, 1223-1232. (In Chinese)

35. Hou, Z.Q.; Yang, Z.S.; Lü, Q.T.; Zeng, P.S.; Xie, Y.L.; Meng, Y.F.; Tain, S.H.; Xu, W.Y.; Li, H.Y.; Jiang, Z.P.; et al. The large-scale Dongguashan deposit, Shizishan district in East China: Carboniferous sedex-type massive sulfides overprinted by late Jurassic skarn Cu mineralization. Acta Geol. Sin. 2011, 5, 659-686. (In Chinese)

36. Jiang, S.Y.; Ding, Q.F.; Yang, S.Y.; Zhu, Z.Y.; Sun, M.Z.; Sun, Y.; Bian, L.Z. Discovery and significance of carbonate mud mounds from Cu-polymetallic deposits in the Middle and Lower Yangtze Metallogenic Belt: Examples from the Wushan and Dongguashan deposits. Acta Geol. Sin. 2011, 85, 744-756. (In Chinese)

37. Gu, L.X.; Chen, P.Y.; Ni, P.; Xu, Z.W.; Xiao, J.X.; Qiu, J.S.; Zhang, Z.Z.; Zhang, G.H. Comparative research on ore-forming fluids for the main types of hydrothermal copper-gold deposits in the Middle and Lower Reaches of the Yangtze River. J. Nanjing Univ. (Nat. Sci.) 2002, 38, 392-407. (In Chinese)

38. Xu, J.H.; Xie, Y.L.; Yang, Z.S.; Meng, Y.F.; Zeng, P.S. Trace elements in fluid inclusions of submarine exhalation-sedimentation system in Tongling metallogenic province. Miner. Depos. 2004, 23, 344-352. (In Chinese)

39. Xu, W.Y.; Hou, Z.Q.; Yang, Z.S.; Shi, D.N.; Meng, Y.F.; Zeng, P.S. Numerical simulation of fluid migration during ore formation of Carboniferous exhalation-sedimentary massive sulfide deposits in the Tongling District, Anhui Province. Acta Geol. Sin. 2005, 79, 98-105.

40. Zhang, Y.; Shao, Y.J.; Wu, C.D.; Chen, H.Y. LA-ICP-MS trace element geochemistry of garnets: Constraints on hydrothermal fluid evolution and genesis of the Xinqiao $\mathrm{Cu}-\mathrm{S}-\mathrm{Fe}-\mathrm{Au}$ deposit, eastern China. Ore Geol. Rev. 2017, 86, 426-439. [CrossRef]

41. Ma, X.; Ge, H. Precambrian crustal evolution of eastern Asia. J. Asia Earth Sci. 1989, 3, 9-15. 
42. Zhai, Y.S.; Yao, S.Z.; Lin, X.D.; Zhou, X.N.; Wan, T.F.; Jin, F.Q.; Zhou, Z.G. Fe-Cu-Au Metallogeny of the Middle-Lower Changjiang Region; Geological Publishing House: Beijing, China, 1992; pp. 1-235. (In Chinese)

43. Liu, W.C.; Gao, D.Z.; Chu, G.Z. Analysis of Tectonic Deformation and Metallogenic Prognosis in Tongling Area, Anhui Province; Geological Publishing House: Beijing, China, 1996; pp. 1-130. (In Chinese)

44. Peng, S.L.; Lai, J.Q.; Mao, X.C.; Shao, Y.J.; Yang, M.; Yang, B. Theories and Technologies for Large-Scale Location and Quantification Prediction of Concealed Ore Bodies in the Depths of Crisis Mines; Geological Publishing House: Beijing, China, 2012; pp. 1-352. (In Chinese)

45. Wu, C.L.; Guo, X.Y.; Wang, C.S.; Wu, X.P.; Gao, Y.H.; Lei, M.; Qin, H.P.; Liu, C.H.; Li, M.Z.; Chen, Q.L. Zircon $\mathrm{U}-\mathrm{Pb}$ dating of high-K calc-alkaline intrusive rocks from Tongling: Implications for the tectonic setting. Geochimica 2013, 42, 11-28. (In Chinese)

46. Xu, X.C.; Bai, R.Y.; Xie, Q.Q.; Lou, J.W.; Zhang, Z.Z.; Liu, Q.N.; Chen, L.W. Re-understanding of the geological and geochemical characteristics of the Mesozoic intrusive rocks from Tongling area of Anhui Province, and discussions on their genesis. Acta Petrol. Sin. 2012, 28, 3139-3169. (In Chinese)

47. Xu, X.C.; Zhang, Z.Z.; Liu, Q.N.; Lou, J.W.; Xie, Q.Q.; Chu, P.L.; Frost, R.L. Thermodynamic study of the association and separation of copper and gold in the Shizishan orefi eld, Tongling, Anhui Province, China. Ore Geol. Rev. 2011, 43, 347-358. [CrossRef]

48. Liu, J.P.; Rong, Y.N.; Zhang, S.G.; Liu, Z.F.; Chen, W.K. Indium Mineralization in the Xianghualing Sn-Polymetallic Orefield in Southern Hunan, Southern China. Minerals 2017, 7, 173. [CrossRef]

49. Carpenter, R.H.; Desborough, G.A. Range insolution and structure of natural occurring troilite and pyrrhotite. Am. Mineral. 1964, 49, 1350-1365.

50. Xi, A.H.; Ren, H.M.; Zhang, B.F.; Wang, Y.X.; Zhi, X.J. Characteristics on ore minerals in Hongqiling Cu-Ni sulfide deposit, Jilin Province. J. Jilin Univ. 2004, 3, 338-343. (In Chinese)

51. Arnold, R.G. Pyrrhotite phase relations below $304 \pm 6{ }^{\circ} \mathrm{C}$ at $<1$ atom total pressure. Econ. Geol. 1969, 64, 405-419. [CrossRef]

52. Mei, J.M. Chemical typomorphic characteristic of pyrites from Zhilingtou gold deposit, Suichang, Zhejiang. Geoscience 2000, 14, 51-55.

53. Li, J.L.; Zhang, Y.M.; Gu, X.X.; Meng, F.J.; Gao, H.J.; Wang, L. Geological characteristics of the Xiyi MVT-type $\mathrm{Pb}-\mathrm{Zn}$ ore deposit in Yunnan and EPMA analysis of the sulfides. Geol. Explor. 2017, 53, 23-34. (In Chinese)

54. Gregory, D.D.; Large, R.R.; Halpin, J.A.; Lounejeva, E.B.; Lyons, T.W.; Wu, S.; Danyushevsky, L.V.; Sack, P.; Chappaz, A.; Maslennikov, V.V.; et al. Trace element content of sedimentary pyrite in black shales. Econ. Geol. 2015, 110, 1389-1410. [CrossRef]

55. Song, H.B. Application of pyrite in gold deposit geology. Geol. Explor. 1989, 25, 31-37. (In Chinese)

56. Zhou, X.W.; Li, S.R.; Lu, L.; Li, J.J.; Wang, J.Z. Study of Pyrite typomorphic characteristics of Wulong quartz-vein-type gold deposit in Dandong, Liaoning Province, China. Geoscience 2005, 19, 231-238.

57. Cromie, P.; Makoundi, C.; Zaw, K.; Cook, D.R.; White, N.; Ryan, C. Geochemistry of Au-bearing pyrite from the Sepon Mineral District, Laos DPR, Southeast Asia: Implications for ore genesis. J. Asian Earth Sci. 2018, 164, 194-218. [CrossRef]

58. Yang, Z.; Yang, L.Q.; Liu, J.T.; Meng, J.Y.; Lü, L.; Sun, N.; Zhang, G.N.; Long, F. Mineralogy typomorphic characteristics of pyrrhotite and mineralization significance of Yangla copper deposit Yunnan China. Acta Petrol. Sin. 2014, 30, 2669-2680.

59. Xu, X.C.; Fan, Z.L.; He, J.; Liu, X.; Liu, X.Y.; Xie, Q.Q.; Lu, S.M.; Lou, J.W. Metallogenic model for copper-gold-polymetallic deposits in Shizishan ore-field, Tongling, Anhui Province. Acta Petrol. Sin. 2014, 4, 1054-1074.

60. Lu, J.J.; Hua, R.M.; Xu, Z.W.; Gao, J.F.; Li, J. A two-stage model for formation of the Dongguahsan Cu-Au deposit. Geol. J. China Univ. 2003, 4, 678-690. (In Chinese)

61. Keith, M.; Hackel, F.; Haase, K.M.; Schwarz-Schampera, U.; Klemd, R. Trace element systematics of pyrite from submarine hydrothermal vents. Ore Geol. Rev. 2016, 72, 728-745. [CrossRef]

62. Li, H.Y.; Li, Y.J.; Yuan, W.M.; Yang, Q.R.; Kang, G.L.; Cao, J.F. Mineral geochemistry in the Dashui diorite-type gold deposit, Gansu Province. Geol. Prospect. 2007, 43, 41-45. (In Chinese)

63. Li, Z.J.; Huang, Y.; Tang, J.X.; Zhang, L.; Lang, X.H. Typomorphic characteristics and significance of pyrrhotite in Xiongcun Cu-Au deposit. Acta Miner. Sin. 2012, 32, 205-210. (In Chinese)

64. Vinogradov, A.P. Average content of chemical elements in the chief types of igneous rocks of the crust of the Earth. Geokhimia 1962, 7, 555-571. 
65. Xu, G.F.; Shao, J.L. Typomorphic characteristics of pyrite and its significance. Geol. Rev. 1980, 26, 541-546. (In Chinese)

66. Doyle, F.M.; Mirza, A.H. Electrochemical oxidation of pyrite samples with known composition and electrical properties. Electrochem. Proc. 1996, 96, 203-214.

67. Oberthur, T.; Cabri, L.J.; Weiser, T.W.; McMahon, G.; Muller, P. Pt, Pd and other trace elements in sulfides of the mainsulfide zone, Great Dyke, Zimbabwe: A reconnaissance study. Can. Miner. 1997, 35, 597-609.

68. Li, H.B.; Zeng, F.Z. The pyrite's typomorphic characteristics in gold deposit. Contrib. Geol. Miner. Resour. Res. 2005, 20, 199-203.

69. Bralia, A.; Sabatini, G.; Troja, F. A revaluation of the $\mathrm{Co} / \mathrm{Ni}$ ratio in pyrite as geochemical tool in ore genesis problems. Miner. Depos. 1979, 14, 353-374. [CrossRef]

70. Chen, D.F. Characteristics of main metallic minerals in some copper-nickel sulfide deposits of China. Acta Petrol. Miner. 1995, 14, 345-354. (In Chinese)

71. Cook, N.J.; Ciobanu, C.L.; Mao, J. Textural control on gold distribution in As-free pyrite from the Dongping, Huangtuliang and Hougou gold deposits, North China Craton (Hebei Province, China). Chem. Geol. 2009, 264, 101-121. [CrossRef]

72. Bajwah, Z.U.; Seccombe, P.K.; Offler, R. Trace element distribution, Co/Ni ratios and genesis of the Big Cadia iron-copper deposit, New South Wales, Australia. Miner. Depos. 1987, 22, 292-300. [CrossRef]

73. Gregory, D.D.; Lyons, T.W.; Large, R.R.; Jiang, G.P.; Stepanov, A.S.; Diamond, C.W.; Figueros, M.C.; Olin, P. Whole rock and discrete pyrite geochemistry as complementary tracers of ancient ocean chemistry: An example from the Neoproterozoic Doushantuo Formation, China. Geochim. Cosmochim. Acta 2017, 216, 201-220. [CrossRef]

74. Koglin, N.; Frimmel, H.E.; Lawrie Minter, W.E.; Bratz, H. Trace-element characteristics of different pyrite types in Mesoarchaean to Palaeoproterozoic placer deposits. Miner. Depos. 2010, 45, 259-280. [CrossRef]

(C) 2018 by the authors. Licensee MDPI, Basel, Switzerland. This article is an open access article distributed under the terms and conditions of the Creative Commons Attribution (CC BY) license (http:/ / creativecommons.org/licenses/by/4.0/). 